\title{
Efficacy of Foliar Spray of Two Biostimulants in Phytoremediation and Overcoming Salinity Stress in Halophytic Grass, Puccinellia Distans
}

\section{Saeed Hosseini}

Shahrekord University

Leila Shabani ( $\sim$ Ishabani@gmail.com )

Shahrekord University https://orcid.org/0000-0001-6194-4708

Mohammad R. Sabzalian

Isfahan University of Thechnology

Shima Gharibi

Isfahan University of Medical Science

\section{Original Article}

Keywords: Antiporters, Biostimulant, Phytoremediation, Puccinellia distans, Salinity

Posted Date: October 18th, 2021

DOI: https://doi.org/10.21203/rs.3.rs-957562/v1

License: @ (i) This work is licensed under a Creative Commons Attribution 4.0 International License. Read Full License 


\section{Abstract}

Background: Plants pre-treatment with various chemicals has often been used to diminish salinity stress impact on plants. In the present study, we used foliar spray of two commercially biostimulants (Algabon ${ }^{\circledR}$ and Bomamid ${ }^{\circledR}$ ) before the stress, to study interactive effects of biostimulants and salinity stress in halophytic grass, Pucccinellia distans.

Results: Our results showed that biomass, leaf relative water content, chlorophyll content, $\mathrm{K}^{+}$content, $\mathrm{K}^{+} / \mathrm{Na}^{+}$ratio, and protein and $\mathrm{N}$ contents were also negatively affected by $300 \mathrm{mM} \mathrm{NaCl}$. The results obtained in the present study showed the beneficial effects of the pre-treatments of two biostimulants on $P$. distans seedlings under non salinity stress conditions with respect to increasing plant biomass, photosynthetic pigments, $\mathrm{K}^{+}$content, the content of proteins and nitrogen percentage. The results suggested that foliar spray of Bonamid could considerably diminish $\mathrm{NaCl}$-caused stress on $P$. distans seedlings, probably due to higher accumulation of shoot biomass, photosynthetic pigments, $\mathrm{K}^{+} / \mathrm{Na}^{+}$ratio, protein and $\mathrm{N}$ contents, phytoremediation potential, as well as upregulation of $\mathrm{Na}^{+} / \mathrm{H}^{+}$antiporters located in plasma membranes and vacuoles.

Conclusions: Collectively, it could be concluded that, intensification of osmotic adjustment by the accumulation of osmotic metabolites and the compartmentalization of salts in vacuoles in pre-treated plants with amino acid-derived biostimulant (Bonamid) can diminish the $\mathrm{NaCl}$-induced deleterious effects in $P$. distans seedlings.

\section{Introduction}

As the population grows, the demand for more food increases, and in such circumstances, the use of halophyte plants, which cover a large part of the world's land, has particular value. Therefore, todays, bio-salinity research has led studies towards salinity-resistant plants. In Asia, Iran is one of the countries with the highest level of saline soils and arid and semi-arid climate of this country contributes to the establishment of saline soils in different regions. According to Food and Agriculture Organization's (FAO's), more than $81 \%$ of Iran's irrigated land is exposed to secondary soil salinization (Dewan and Famouri 1964). Considering the large area of saline, alkaline and alkaline pastures in Iran, as well as the reduction of usable forage and natural process of wind erosion, the conditions require extensive studies in the field of halophytes plants.

Halophytes are plants that are able to survive and reproduce at high concentration of salts, exceeding $200 \mathrm{mM} \mathrm{NaCl}$ (Yuan et al. 2019). According to their reaction to salinity, halophytes can be divided into three categories: euhalophytes, recretohalophytes and pseudo-halophytes. Pseudo-halophytes of the genus Puccinellia are able to tolerate high salinity levels due to the thickening of the root endoderm that restricts the $\mathrm{Na}^{+}$entry and compartmentalizes $\mathrm{Na}^{+}$into their vacuoles (Yuan et al. 2019; Dashtebani et al. 2014). Data on the basic ionic and biochemical mechanisms that cause salinity tolerance in halophytes is limited to some model species, principally dicotyledons (Dashtebani et al. 2014). In view of the fact that many commercially major crops are monocotyledonous glycophytes, understanding the salt tolerance mechanisms in monocotyledonous halophytes will help breeding programs to improve salt tolerance in cereals. P. distans coming from family Poaceae, is a monocotyledonous halophyte that is distributed in the north, northwest and central parts of Iran. It can typically grow in saline and alkaline soils with high underground water table or heavy soils with moderate drainage (Akhani, 2006) and is regarded as one of the most favorable grass species for saline rangelands stabilizing and for preventing erosion.

Salinity suppresses the growth and development of plants by influencing major metabolic processes and by creating ionic and osmotic stresses (Van Zelm et al. 2020). Moreover, another detrimental effect of salinity, like other abiotic stresses, is the generation of oxidative stress through increased production of reactive oxygen species (ROS). The most of review papers have shown that the mechanisms of salinity tolerance in salt tolerant plants include reduction of $\mathrm{Na}^{+}$ 
entry and their accumulation into vacuoles by $\mathrm{Na}^{+} / \mathrm{H}^{+}$antiporters (SOS1 in plasma membrane and NHX1 in tonoplast), increment of $\mathrm{Na}^{+}$exclusion from shoot and intracellular compartmentations, keeping of high $\mathrm{K}^{+} / \mathrm{Na}^{+}$ratio in cytosol in addition to biosynthesis and accumulation of osmoprotectants and enzymatic and nonenzymatic antioxidants (Bartels and Sunkar 2005; Flowers et al. 2015; Van Zelmet al. 2020).

Salt stress tolerance in plants can be improved by different approaches including genetic manipulations (Van Zelm et al. 2020), mycorrhization (Evelin et al. 2019), the application of organic matter and biofertilizers, seeds pre-treatments (Masondo et al. 2018; Abdelhamid et al. 2019), foliar application of organic and inorganic substances and the application of biostimulants (Latef et al. 2017; Zahedi et al. 2020). According to the definition provided recently by du Jardin et al. (2020) biostimulants are regulators of plant life processes that enhance growth and resources usage under stress or non-stress conditions. They categorised biostimulants into seven classes, including: seaweed and plants extracts, protein hydrolysates and $\mathrm{N}$-containing compounds, humic and fulvic acids, chitosan and other biopolymers, inorganic compounds and beneficial fungi and bacteria (Du Jardin 2015).

Biostimulants contain biologically active compounds and by enhancing primary and secondary metabolisms (Bulgari et al. 2015; Yakhin et al. 2017) can improve plant growth stimulation by enhancing the efficiency of water, photosynthesis, and increasing the absorption of nutrients from soil and neutralizing abiotic stresses (Van Oosten et al. 2017; Yakhin et al. 2017). The key mechanisms induced by biostimulants are complicated and investigation is still ongoing. They are able to change some molecular processes that allow to improve plant tolerance to salinity by supporting better status of water and increasing dry biomass, chlorophyll content, and nitrate concentration, enhanced ROS scavenging enzymes, increasing endogenous osmoprotectants, reduced membrane leakage and influencing phyto-hormones (Fasciglione et al. 2015; Rady et al. 2019; Rady and Mohamed 2015; Bulgari, Franzoni, and Ferrante 2019). Biostimulants can be used as foliar spray or in soil, depending on their composition and the favourable performance (Kunicki et al. 2010).

Although earlier researches have reported an important role of biostimulants in improving stress resistance in plants (Rouphael et al. 2017; Desoky et al. 2018; Di Stasio et al. 2018; Bulgari et al. 2019), it is not clear exactly how these compounds act under stress. The efficiency of biostimulants to neutralize the stress condition in plants relies on different parameters, such as mode of application of biostimulants, timing of application and their concentrations, and variability, intensity and duration of the stresses. Hence, in this experiment, we used foliar spray of two biostimulants (Algabon ${ }^{\circledR}$ and Bonamid $\AA$ ) before the stress (pre-treatment) with the concentrations suggested by the manufacturer company, to study the interactive effects of biostimulants and salinity stress in halophytic grass, $P$. distans.

\section{Material And Methods}

\section{Chemicals}

In this study, we used two biostimulants (Algabon ${ }^{\circledR}$ and Bonamid $($ ) ) available in the market (Bon Asia Cultivation Company) each with very distinct formulizations; Algabon ${ }^{\circledR}$, seaweed extract-derived biostimulant, containing guaranteed ingredients: alginic acid (18\%), $\mathrm{NO}_{3}(1 \%), \mathrm{K}_{2} \mathrm{O}(16 \%), \mathrm{H}_{2} \mathrm{PO}_{4}(1 \%)$ and Bonamid $\circledast$ as amino acid-derived biostimulant, containing guaranteed ingredients: amino acid (85\%), nitrogen (4\%).

\subsection{Plant culture and treatments}

The seeds of Puccinellia distans were collected from Chargholi coastal area in Golestan Province of Iran (E 54 $00^{\prime}, N^{\prime}$ $\left.36^{\circ} 58^{\prime}\right)$. The surface-sterilized seeds of $P$. distans were germinated in petri dishes for 48 hours to obtain seedlings. The seedlings were placed in plastic pots (15-cm upper diameter, 12-cm lower diameter, and 15-cm depth) that were filled with $2 \mathrm{~kg}$ of soil mixture (filled with soil and animal manure in a ratio of 4 to 1 ). All the pots were irrigated with $200 \mathrm{ml}$ of 
half-strength Hoagland's solution. The seedlings grew in the greenhouse condition at $25 \pm 2^{\circ} \mathrm{C}$ with a relative of humidity of $70 \%$ supplied with a $14 / 10 \mathrm{~h}$ photoperiod for 45 days to adjust the conditions and produce abundant materials for later experiments.

\section{First experiment}

In the first experiment, the 45-day old seedlings were irrigated with $200 \mathrm{ml}$ of half-strength Hoagland's nutrition containing four concentrations of $\mathrm{NaCl}(0,300,600$ and $900 \mathrm{mM})$ thrice for one a week. This experiment was performed in a completely randomized design with three replications. Plants were grown under the same condition stated in the former section. After one week, seedlings were harvested and shoot fresh and dry weights, RWC and salt tolerance index (STI) were determined by the methods described in the following sections. Based on the results, the concentration of 300 $\mathrm{mM}$ of $\mathrm{NaCl}(\mathrm{EC}=27.18 \mathrm{dS} / \mathrm{m})$ was selected as the moderate stress in the second experiment.

\section{Second experiment}

In the second experiment, we studied the effects of foliar spray of two biostimulants (Algabon ${ }^{\circledR}$ and Bonamid $\AA$ ) before the stress (pre-treatment) with the concentrations $0.5 \mathrm{~g} / \mathrm{l}$ and $2 \mathrm{~g} / \mathrm{l}$, respectively, under normal and salinity stress conditions. To this objective, 45-day old seedlings were pre-treated with foliar spraying of $0.5 \mathrm{~g} / \mathrm{l}$ Algabon and $2 \mathrm{~g} / \mathrm{l}$ Bonamid thrice for two week. To improve the efficacy of foliar uptake, Tween 80 was added to the spray solutions. Control seedlings were sprayed with distilled water. Then, a half of pre-treated seedlings were irrigated with half-strength Hoagland's nutrition containing $300 \mathrm{mM}$ of $\mathrm{NaCl}$ for 15 days. The other half of the seedlings were irrigated with halfstrength Hoagland's nutrition as a control. The experiment was planned as a factorial combination of three biostimulants treatments (Water, Algabon $\AA$ and Bonamid $\left.{ }^{\circledR}\right)$ and two salinity solutions (control $(0 \mathrm{mM} \mathrm{NaCl})$ and salinity $(300 \mathrm{mM} \mathrm{NaCl})$. The treatments were organized in a completely randomized design with 3 replications per treatment.

\subsection{Measurement of growth characteristics}

At the end of two experiments, the seedlings were harvested. The plant samples were rinsed with tap water and then separated into shoots and roots, and then weighed to determine the fresh weight. The plant parts were dried at $70^{\circ} \mathrm{C}$ for $48 \mathrm{~h}$. Leaf relative water content (RWC) was calculated using the following formula (Barrs and Weatherley 1962): RWC $(\%)=$ [fresh weight of leaf samples-dry weight of leaf samples/turgid weight of leaf samples-dry weight of leaf samples] $\times 100$. Salt tolerance index (STI) was calculated by the following formula (Goudarzi and Pakniyat 2008): (STI) $\%=($ Mean shoot dry weight in the treatment/Mean shoot dry weight in control $) \times 100$. The dried shoot and root samples were weighed, and used to determine the shoots and roots water contents (Fresh weight- Dry weight / Fresh weight×100).

\subsection{Photosynthetic pigments determination}

The absorbance of acetone extracts of leaves was read at 663, 645 and $470 \mathrm{~nm}$ for the measurement of chlorophylls and carotenoid concentrations according to the methods defined by Arnon (1949) and Lichtenthaler (1987), respectively.

\subsection{Determination of proline content}

Proline content was estimated using the method of Troll and Lindsley (1955). After extracting $0.1 \mathrm{~g}$ of leaves in $90 \%$ ethanol, the mixture was centrifuged at $14000 \times \mathrm{g}$ for $5 \mathrm{~min}$. A reaction mixture containing acetic acid, $96 \%$ ( $/ \mathrm{v}$ ) ethanol and ninhydrin was added to the supernatant. After centrifuging and boiling, proline content was measured at $520 \mathrm{~nm}$ and was calculated as $\mu \mathrm{mol} / \mathrm{g}$ FW against standard proline.

\subsection{Determination of glycine betaine content}


The glycine betaine content was determined according to Grieve and Grattan (1983) with minor modifications. Briefly, deionized $\mathrm{H}_{2} \mathrm{O}$ extracts were diluted $1: 1$ with $2 \mathrm{~N} \mathrm{H}_{2} \mathrm{SO}_{4}$ and cooled in ice water for $1 \mathrm{~h}$. Then, $200 \mu \mathrm{l}$ cold $\mathrm{KI}-\mathrm{I}_{2}$ reagent was added and stored at $4^{\circ} \mathrm{C}$ for $16 \mathrm{~h}$. The resulting mixture was centrifuged at $10000 \mathrm{rpm}$ for $15 \mathrm{~min}$ at $4^{\circ} \mathrm{C}$. The deposited periodide crystals in the tubes were dissolved in $9 \mathrm{ml}$ of 1,2-dichloroethane, and the mixture was shaken vigorously. After $2 \mathrm{~h}$, the absorbance was measured at $365 \mathrm{~nm}$. The content of glycine betaine was calculated based on a standard curve of standard solutions of glycine betaine.

\subsection{Determination of total phenolic content}

Total phenolic content was determined by the method proposed by Singleton and Rossi (1965), which is also known as the Folin- Ciocalteau reagent technique. The basis of this method is the reduction of the reagent by phenolic compounds in alkaline medium and the formation of a blue complex that shows the maximum absorption at a wavelength of 750 $\mathrm{nm}$. In a test tube, $9 \mathrm{ml}$ of distilled water was added to $1 \mathrm{ml}$ of the plant methanolic extract. Then, $1 \mathrm{ml}$ of diluted reagent was added and the mixture was shaken vigorously. After 5 minutes, we added $10 \mathrm{ml}$ of sodium carbonate $\left(\mathrm{Na}_{2} \mathrm{CO}_{3}\right)$ (7\%). Then, $4 \mathrm{ml}$ of distilled water was added to the resulting mixture and the final volume was set to $25 \mathrm{ml}$. The reaction mixture was incubated at room temperature for 90 minutes and the absorbance was measured at a wavelength of 750 $\mathrm{nm}$. Total phenolic acids were expressed in milligrams of gallic acid per gram of sample.

\subsection{Determination of Protein}

The protein concentration of leaves and roots of each samples was determined following the method of Bradford (1976) using BSA as a protein standard. Total protein content was expressed as milligram per gram of leaf dry weight (mg/g DW).

\subsection{Determination of soluble sugar concentration}

Freeze-dried leaves and roots $(100 \mathrm{mg})$ were used for the determination of soluble sugar concentration. It was extracted in $5 \mathrm{ml} 80 \%$ ethanol $(\mathrm{v} / \mathrm{v})$. After boiling the extracts and centrifuging them using anthrone reagent, absorption of samples was read at $625 \mathrm{~nm}$ (Porter and Villar 1997).

\subsection{Determination of antioxidant capacity (DPPH scavenging activity)}

Assessment of DPPH (1,1-diphenyl-2-picrylhydrazyl) radical scavenging capacity was performed by preparing $500 \mu \mathrm{l}$ of sample ethanolic extract in a tube. Then, $500 \mu \mathrm{l}$ of DPPH solution was added to the extract. The solution was thoroughly mixed and incubated at room temperature for 30 minutes. The absorbance of control ethanol sample (blank), control water sample and samples obtained from plant extracts was read at $520 \mathrm{~nm}$ (Kulisic et al. 2004). The capacity of scavenging free radicals of samples was calculated as follows:

\% Radical Scavenging Activity=((OD control water -OD Sample)/OD control water)*100

\subsection{Determination of total nitrogen}

For estimation of total $\mathrm{N}, 1 \mathrm{~g}$ of fine-ground leaves and roots dry samples was digested with sulphuric acid, and assays were carried out according to the Kjeldahl method (1883)

\subsection{Determination of elements}

The concentration of elements $\left(\mathrm{Na}^{+}\right.$and $\left.\mathrm{K}^{+}\right)$in $0.5 \mathrm{~g}$ ground dried powder of leaves and roots sample was determined by ICP-OES (Genesis, Spectro Company, Germany). 
Phytoremediation potential was determined according to Fischer and Maurer (1978) by the ion uptake of the plants as follows: PP $\left(\mathrm{g} \cdot \mathrm{m}^{-1}\right)=\left(\mathrm{Na}^{+}\right.$concentration $\left(\mathrm{mg} \cdot \mathrm{g}^{-1}\right) \times$ biomass $(\mathrm{g}$ dry weight $) /$ pot area $\left.\left(\mathrm{m}^{2}\right)\right) / 1000$. Where, PP is the phytoremediation potential of shoots or total biomass (shoots + roots) in each treatment based on $\mathrm{Na}^{+} / \mathrm{m}^{2}$ of surface area.

\subsection{RNA extraction, cDNA synthesis and quantitative real-time PCR}

Total RNA was extracted from fresh leaf and root tissues of $P$. distans by means of the DENA zist ASIA kit (DENAzist Asia Co., \# S-1010-1, Iran) according to the manufacturer's instruction. The first-strand cDNA was synthesized using PrimeScript RT Enzyme Mix I enzyme (PrimeScript ${ }^{\text {TM }}$ RT reagent Kit, Takara company Inc., Otsu, Japan) according to the manufacturer's protocol. The primers for beta-actin (Actin), plasma membrane $\mathrm{Na}^{+} / \mathrm{H}^{+}$antiporter (SOS1), and tonoplast $\mathrm{Na}^{+} / \mathrm{H}^{+}$antiporter NHX1 (NHX1) genes were taken from Zhang et al. (2017). Information on primers is gave in Table 1. Quantitative real-time PCR was conducted by StepOnePlus ${ }^{\mathrm{TM}}$ Real-Time PCR System (Applied Biosystems, Foster City, CA USA) using SYBR Premix Ex Taq TaKaRa (Takara Bio, Inc., Otsu, Japan). For the reactions, the program of the thermo-

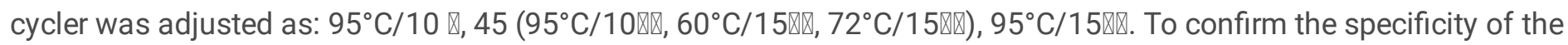
reaction, the melting curve analysis was carried out for PCR reactions. The relative expression levels of all genes were measured using the $2^{-\Delta \Delta C t}$ method (Livak and Schmittgen 2001).

Table 1

Sequences of primers used for quantitative real-time PCR amplification.

\begin{tabular}{|ll|}
\hline Gene name & Sequence $\left(\mathbf{5}^{\prime} \mathbf{-} \mathbf{3}^{\prime} \mathbf{)}\right.$ \\
\hline Actin & Actin-F 5-TTGACTACGACCAGGAGATGGA-3 \\
\hline Actin & Actin-R 5-TGAAGGATGGCTGGAAGAGG-3 \\
SOS1 & SOS1-F 5-GACGAATAACTCAATCCACAGCAA-3 \\
\hline SOS1 & SOS1-R 5-ACCGCAAACCCTTCCAATC-3 \\
NHX1 & NHX1-F 5-GCAATGAACTCCGCAATGATAC-3 \\
\hline NHX1 & NHX1-R 5-GCTGTAATGCTTCCTTCTCTTCCT-3 \\
\hline
\end{tabular}


Table 1

Fresh and dry weights of shoots and roots, root/shoot ratio (DW) and RWC in salinity condition (SC) and non-salinity condition (NSC) Puccinellia distans exposed to foliar spraying of biostimulants. Different letters indicate significant differences according to LSD tests $(p<0.05)$.

\begin{tabular}{|c|c|c|c|c|c|c|}
\hline \multirow{2}{*}{$\begin{array}{l}\text { Biostimulants } \\
\text { Treatments }\end{array}$} & \multicolumn{2}{|c|}{ Shoot fresh weight (g) } & \multicolumn{2}{|c|}{ Shoot dry weight (g) } & \multicolumn{2}{|l|}{ RWC (\%) } \\
\hline & NSC & SC & NSC & SC & NSC & SC \\
\hline Control & $14.60 \pm 0.49^{c}$ & $8.20 \pm 0.05^{\mathrm{e}}$ & $2.75 \pm 0.04^{c}$ & $1.38 \pm 0.07^{f}$ & $96.38 \pm 0.59^{b}$ & $78.50 \pm 1.80^{d}$ \\
\hline Algabon & $15.8 \pm 0.10^{b}$ & $13.42 \pm 0.08^{d}$ & $2.95 \pm 0.05^{b}$ & $2.15 \pm 0.05^{\mathrm{e}}$ & $97.27 \pm 0.51^{\mathrm{b}}$ & $87.79 \pm 0.97^{c}$ \\
\hline \multirow[t]{3}{*}{ Bonamid } & $17.7 \pm 0.09^{a}$ & $15.86 \pm 0.51^{b}$ & $3.28 \pm 0.07^{a}$ & $2.4 \pm 0.05^{d}$ & $101.18 \pm 1.20^{\mathrm{a}}$ & $88.21 \pm 0.18^{c}$ \\
\hline & \multicolumn{2}{|c|}{ Root fresh weight (g) } & \multicolumn{2}{|c|}{ Root dry weight (g) } & \multicolumn{2}{|c|}{ Root/Shoot (DW) } \\
\hline & NSC & SC & NSC & SC & NSC & SC \\
\hline Control & $5.22 \pm 0.01^{\mathrm{e}}$ & $4.60 \pm 0.04^{f}$ & $0.85 \pm 0.05^{\mathrm{cd}}$ & $0.68 \pm 0.07^{e}$ & $0.30 \pm 0.21^{d}$ & $0.49 \pm 0.08^{b}$ \\
\hline Algabon & $6.60 \pm 0.07^{b}$ & $5.34 \pm 0.07^{d}$ & $1.15 \pm 0.04^{b}$ & $0.78 \pm 0.07^{\text {de }}$ & $0.39 \pm 0.02^{c}$ & $0.36 \pm 0.03^{c d}$ \\
\hline Bonamid & $9.47 \pm 0.06^{a}$ & $6.32 \pm 0.02^{c}$ & $2.1 \pm 0.10^{a}$ & $0.95 \pm 0.05^{c}$ & $0.63 \pm 0.01^{\mathrm{a}}$ & $0.39 \pm 0.02^{c}$ \\
\hline
\end{tabular}

\section{Statistical Analysis}

The first experiment was managed in a completely randomized design (CRD) with three replications. The second experiment was conducted as factorial test in a completely randomized design with three replications. Data were analysed according to the GLM procedure of SAS statistical software (version 8; SAS Institute Inc., Cary, NC, United States). A standard Fisher's test was applied to determine significant differences between treatments. Significance was determined with $a \leq 0.05$.

\section{Results}

\subsection{Plant growth measurements}

Results related to the first experiment showed that shoot fresh and dry weights, RWC content and salt tolerance index (STI) were significantly affected by $\mathrm{NaCl}$ at all applied concentrations in comparison to the control, with the maximum reduction in seedlings treated with $900 \mathrm{mM}$ of NaCl (Figure. 1). However, there was no significant difference between 300,600 and $900 \mathrm{mM}$ of $\mathrm{NaCl}$ concentrations in shoot dry weight and salt tolerance index (STI) in the seedlings of Puccinellia distans. STI values based on shoot dry weight indicated no difference in salt tolerance among the three concentration of $\mathrm{NaCl}$ applied in this study. Application of $300 \mathrm{mM} \mathrm{NaCl}$ decreased salt tolerance index by $50.06 \%$ in comparison to control, therefore, it was selected for the study of interaction with bio-stimulants. Dissociation of roots and the dry weight measurements were not easily feasible due to the type of bed we used for plant cultivation.

Nonetheless, root density in the seedlings of $P$. distans notably decreased with increasing salinity stress level (Figure. 2).

\subsection{Effects of foliar spray of biostimulants on shoot and root growth under salinity stress}

Difference in growth and morphology of $P$. distans seedlings under various treatments is shown in figure 3 . Evaluation of vegetative growth parameters in $P$. distans seedlings showed that two biostimulant pre-treatments considerably enhanced these parameters under both NSC and SC. Under non-salinity condition, shoot FW and DW increased by 8.2 and 7.2\% and in Algabon and 21.2 and 19.4\% in Bonamid-sprayed plants, respectively (Table 1). Furthermore, root FW 
and DW increased by 26.3 and $35.3 \%$ in Algabon and $81 \%$ and 2.5 fold in Bonamid-sprayed plants, respectively, in comparison with water-sprayed plants in non-salinity condition. Also, in this condition, the highest RWC and root/shoot ratio (DW) was observed by the application of foliar spray of Bonamid by $5 \%$ and 2 fold, respectively. Salinity stress led to a decrease of SFW, SDW, RFW, RDW and RWC by 43, 49, 12, 20 and 18.5\%, respectively, in water-sprayed plants under $\mathrm{NaCl}$ stress and root/shoot ratio (DW) increased by $60 \%$ compared with their NSC counterparts (Table 1). Pre-treatments of $P$. distans leaves with foliar spray of two biostimulants considerably alleviated salinity stress-induced growth reduction. Algabon enhanced SFW, SDW and RFW by 63,55 and $16 \%$, respectively, while Bonamid enhanced the respective parameters by $93.4,73.5$ and $37.2 \%$ as compared with salinity-stressed plants exposed to water-sprayed treatment. Although there was no significant difference between plants foliar sprayed by two biostimulants in SFW and root/shoot ratio (DW), the highest value of RDW was observed in the plants sprayed with Bonamid.

\subsection{Effects of foliar spray of biostimulants on chlorophyll and carotenoid content under salinity stress}

As shown in figure 4A, the results demonstrated that the total chlorophyll content of $P$. distans seedlings was significantly affected by the application of biostimulants, under NSC and SC. In NSC, the highest value of the total chlorophyll $(1.95 \pm 0.05 \mathrm{mg} / \mathrm{FW})$ was detected by the application of foliar spray of Bonamid. At salinity stress conditions, the total chlorophyll of Algabon and Bonamid-sprayed plants decreased by 8.8 and $22 \%$, respectively, as compared with salinity-stressed plants exposed to water-sprayed treatment. Similarly, at the NSC, the highest value of the carotenoids content $(0.05 \pm 0.001 \mathrm{mg} / \mathrm{FW})$ was also detected by the application of foliar spray of Bonamid in comparison with watersprayed plants in NSC. We observed no significant difference between salinity-stressed plants foliar sprayed by two biostimulants in the carotenoids content compared with plants exposed to water-sprayed treatment in SC (Fig. 4B).

\subsection{Effects of foliar spray of biostimulants on total phenolic, proline, glycine betaine and RSA contents under salinity stress}

According to the results shown in Fig. 5 , the results showed that the application of biostimulants in $P$. distans seedlings significantly influenced on total phenolic, proline and RSA content under NSC and SC. Nonetheless, there was no significant difference in the glycine betaine content between plants in NSC foliar sprayed with biostimulants and the water-sprayed plants. However the highest content of these compounds was found in water-sprayed plants in nonsalinity conditions. Under salinity stress, the total phenolic, proline, and RSA content increased in $P$. distans seedlings pre-treated with two biostimulants as compared with their counterparts grown under NSC.

\subsection{Effects of foliar spray of biostimulants on soluble sugar, protein and nitrogen percentage of shoots and roots under salinity stress}

As shown in Table 2, the soluble sugar content of roots and shoots was influenced by foliar spray of biostimulants. Under salinity stress, the soluble sugar content of roots and shoots increased in $P$. distans seedlings pre-treated with two biostimulants as compared with their counterparts grown under NSC. Upon the application of foliar spray of biostimulants in the NSC, protein content of roots increased by $7 \%$ in Algabon and $12 \%$ in Bonamid-sprayed plants, respectively in comparison with water-sprayed plants in NSC. In salinity conditions the highest protein content of roots and shoots were observed by the application of foliar spray of Bonamid by 6.1 and 9.3, respectively, compared with plants exposed to water-sprayed treatment in SC. In consistent with protein results, the application of biostimulants in $P$. distans seedlings significantly influenced on the percentage of nitrogen content of roots and shoots under NSC and SC. In both conditions, the highest percentage of nitrogen content of roots and shoots was observed in the plants sprayed with Bonamid by 13 and 12\% (in NSC) and 8.2 and 31\% (in SC) compared with plants exposed to water-sprayed treatment counterparts. 
Table 2

Soluble sugar, protein content and percentage of Nitrogen of roots and shoots in salinity condition (SC) and non-salinity condition (NSC) in Puccinellia distans exposed to foliar spraying of biostimulants. Different letters indicate significant differences according to LSD tests $(p<0.05)$.

\begin{tabular}{|c|c|c|c|c|c|c|}
\hline \multirow[t]{2}{*}{$\begin{array}{l}\text { Biostimulants } \\
\text { Treatments }\end{array}$} & \multicolumn{2}{|c|}{$\begin{array}{l}\text { Root soluble sugar } \\
\text { (mg/100g DW) }\end{array}$} & \multicolumn{2}{|c|}{$\begin{array}{l}\text { Shoot Soluble Sugar } \\
\text { (mg/100g DW) }\end{array}$} & \multicolumn{2}{|l|}{$\begin{array}{l}\text { Root Protein } \\
\text { (g/100g DW) }\end{array}$} \\
\hline & NSC & SC & NSC & SC & NSC & SC \\
\hline Control & $0.77 \pm 0.01^{d}$ & $1.64 \pm 0.01^{\mathrm{a}}$ & $2.35 \pm 0.01^{d}$ & $4.48 \pm 0.01^{a}$ & $5.45 \pm 0.01^{c d}$ & $5.22 \pm 0.16^{d}$ \\
\hline Algabon & $0.65 \pm 0.01^{e}$ & $1.50 \pm 0.01^{b}$ & $2.48 \pm 0.01^{\mathrm{e}}$ & $4.05 \pm 0.01^{b}$ & $5.82 \pm 0.01^{b}$ & $5.24 \pm 0.01^{d}$ \\
\hline \multirow[t]{3}{*}{ Bonamid } & $0.37 \pm 0.01^{f}$ & $1.39 \pm 0.00^{c}$ & $2.47 \pm 0.01^{e}$ & $3.59 \pm 0.01^{c}$ & $6.12 \pm 0.00^{a}$ & $5.54 \pm 0.01^{c}$ \\
\hline & \multicolumn{2}{|l|}{$\begin{array}{l}\text { Shoot Protein } \\
(g / 100 g \text { DW) }\end{array}$} & \multicolumn{2}{|c|}{ Percentage of Nitrogen (Root) } & \multicolumn{2}{|c|}{$\begin{array}{l}\text { Percentage of Nitrogen } \\
\text { (Shoot) }\end{array}$} \\
\hline & NSC & SC & NSC & SC & NSC & SC \\
\hline Control & $14.36 \pm 0.01^{b}$ & $11.76 \pm 0.01^{f}$ & $0.87 \pm 0.01^{c}$ & $0.82 \pm 0.00^{e}$ & $2.30 \pm 0.01^{d}$ & $1.81 \pm 0.01^{f}$ \\
\hline Algabon & $13.78 \pm 0.01^{c}$ & $12.22 \pm 0.01^{\mathrm{e}}$ & $0.97 \pm 0.01^{\mathrm{a}}$ & $0.85 \pm 0.00^{d}$ & $2.40 \pm 0.01^{b}$ & $2.27 \pm 0.01^{\mathrm{e}}$ \\
\hline Bonamid & $14.65 \pm 0.01^{\mathrm{a}}$ & $12.85 \pm 0.01^{d}$ & $0.98 \pm 0.00^{a}$ & $0.88 \pm 0.01^{b}$ & $2.58 \pm 0.01^{a}$ & $2.37 \pm 0.01^{c}$ \\
\hline
\end{tabular}

\subsection{Effects of foliar spray of biostimulants on ions of shoots and roots under salinity stress}

The effect of biostimulants and salinity stress on $\mathrm{Na}^{+}, \mathrm{K}^{+}$and $\mathrm{K}^{+} / \mathrm{Na}^{+}$in roots and shoots of in $P$. distans seedlings is shown in Table 3. Salinity stress increased concentrations of $\mathrm{Na}^{+}$in roots and shoots in control plants, however foliar spray of two biostimulants reduced $\mathrm{Na}^{+}$concentration of roots and shoots by 9.5 and $11 \%$ (in Algabon), 9.6 and $13 \%$ (in Bonamid) and lessened detrimental impacts of salinity (Table. 3). Both biostimulants accumulated similar $\mathrm{Na}^{+}$content in roots and shoots in salinity conditions, but a lower $\mathrm{Na}^{+}$level was found in the Bonamid pre-treated P. distans. $\mathrm{K}^{+}$ content of roots and shoots increased by the application of two biostimulants in both NSC and SC. Based on the obtained results, under salinity stress, significant reductions took place in $\mathrm{K}^{+} / \mathrm{Na}^{+}$of both roots and shoots of control plants, however foliar spray of two biostimulants improved this ratio under both NSC and SC. In Both conditions, the highest $\mathrm{K}^{+} / \mathrm{Na}^{+}$ratio of roots was observed in Algabon and Bonamid treatments by 2.5 and 1.6 fold, respectively, whereas there was no significant difference between plants sprayed with two biostimulants in $\mathrm{K}^{+} / \mathrm{Na}^{+}$ratio of shoots. 
Table 3

$\mathrm{Na}^{+}, \mathrm{K}^{+}$and $\mathrm{Na}^{+} / \mathrm{K}^{+}$ratio of shoots and roots in the shoots and total biomass in salinity condition (SC) and non-salinity condition (NSC) in Puccinellia distans exposed to foliar spraying of biostimulants. Different letters indicate significant differences according to LSD tests $(p<0.05)$.

\begin{tabular}{|c|c|c|c|c|c|c|}
\hline $\begin{array}{l}\text { Biostimulants } \\
\text { Treatments }\end{array}$ & $\begin{array}{l}\text { Shoot } \mathrm{Na}^{+} \\
(\mathrm{mg} / \mathrm{g})\end{array}$ & & $\begin{array}{l}\text { Root } \mathrm{Na}^{+} \\
(\mathrm{mg} / \mathrm{g})\end{array}$ & & $\begin{array}{l}\text { Shoot } K^{+} \\
(\mathrm{mg} / \mathrm{g})\end{array}$ & \\
\hline & NSC & SC & NSC & SC & NSC & SC \\
\hline Control & $5.35 \pm 0.10^{e}$ & $10.62 \pm 0.10^{a}$ & $7.22 \pm 0.10^{c}$ & $10.23 \pm 0.09^{a}$ & $33.46 \pm 1.08^{d}$ & $42.30 \pm 0.91^{b}$ \\
\hline Algabon & $5.34 \pm 0.10^{e}$ & $9.43 \pm 0.11^{b}$ & $6.52 \pm 0.10^{d}$ & $9.25 \pm 0.10^{b}$ & $36.22 \pm 1.01^{c}$ & $42.71 \pm 1.12^{b}$ \\
\hline \multirow[t]{3}{*}{ Bonamid } & $6.38 \pm 0.10^{d}$ & $9.23 \pm 0.10^{c}$ & $5.14 \pm 0.09^{e}$ & $9.24 \pm 0.09^{b}$ & $43.50 \pm 0.96^{b}$ & $46.13 \pm 0.95^{a}$ \\
\hline & \multicolumn{2}{|l|}{$\begin{array}{l}\text { Root K+ } \\
(\mathrm{mg} / \mathrm{g})\end{array}$} & \multicolumn{2}{|c|}{ Shoot $\mathrm{K}^{+} / \mathrm{Na}^{+}$} & \multicolumn{2}{|l|}{ Root $\mathrm{K}^{+} / \mathrm{Na}^{+}$} \\
\hline & NSC & SC & NSC & SC & NSC & SC \\
\hline Control & $20.04 \pm 0.98^{d}$ & $16.60 \pm 1.17^{e}$ & $6.26 \pm 0.31^{b}$ & $3.98 \pm 0.04^{e}$ & $2.77 \pm 0.12^{c}$ & $1.62 \pm 0.10^{d}$ \\
\hline Algabon & $30.37 \pm 0.75^{b}$ & $24.12 \pm 0.95^{c}$ & $6.77 \pm 0.06^{a}$ & $4.52 \pm 0.17^{d}$ & $4.65 \pm 0.04^{b}$ & $2.60 \pm 0.07^{c}$ \\
\hline Bonamid & $35.60 \pm 0.85^{a}$ & $24.58 \pm 1.18^{c}$ & $6.81 \pm 0.25^{a}$ & $4.99 \pm 0.05^{c}$ & $6.92 \pm 0.28^{a}$ & $2.65 \pm 0.10^{c}$ \\
\hline
\end{tabular}

\subsection{Effects of foliar spray of biostimulants on phytoremediation potential (PP) under salinity stress}

Estimation of phytoremediation potential (PP) in P. distans seedlings showed that two biostimulant pretreatments considerably enhanced this potential under both NSC and SC. Under NSC, phytoremediation potential of the shoots and the total biomass (shoots+roots) increased by 7.2 and $11.6 \%$ by Algabon and 42.6 and $52.4 \%$ by Bonamid treatments, respectively, in comparison with control treatment (Figure 6). Significant increase in phytoremediation potential of shoots and total biomass were observed in plants foliar sprayed with two biostimulants at salinity stress; the highest phytoremediation potential of shoots and total biomass was detected in the plants sprayed with Bonamid by 50.8 and $42.7 \%$ respectively, relative to that in salinity-stressed control plants.

\subsection{Effects of foliar spray of Bonamid on gene expression of SOS1 and NHX1 under salinity stress}

QPCR was applied to analyse the expression induction of antiporter genes, SOS1 and NHX1 in P. distans pre-treated with Bonamid in roots and shoots, respectively, under both conditions (Figure 7). Under the salinity stress, the expression of SOS1 gene increased, although not significantly, compared to the water sprayed plants. Although the foliar spray of Bonamid significantly increased the expression level of SOS1 $(7.39 \pm 1.55, p>0.05)$ under salinity stress, there was no significant difference between Bonamid pre-treated plants and water sprayed counterparts (Figure 7B). The expression of NHX1 in shoots was also analysed by QPCR (Figure 7B). The results indicated that salinity was able to induce NHX1 gene expression in the shoots of $P$. distans $(6.04 \pm 0.64, p>0.05)$. Furthermore, the plants pre-treated by Bonamid showed significant NHX1 gene expression in both conditions. However, the highest expression of NHX1 $(8.53 \pm 1.08, p>0.05)$ was found in Bonamid-treated plants under salinity stress.

\section{Discussion}




\subsection{Pre-treatment of biostimulants significantly impacted growth and photosynthetic pigments in P. distans seedling under salinity stress}

To assist to our understanding of the effects of efficiency of biostimulants pre-tretament to neutralize the stress condition, we pre-treated $P$. distans seedling with foliar spray of two biostimulants (Algabon ${ }^{\circledR}$ and Bonamid ${ }^{\circledR}$ ), and then exposed them to $300 \mathrm{mM} \mathrm{NaCl}$ and compared responses with those pre-treated with foliar spray of water.

Growth of NSC plants displayed a marked response towards biostimulants pre-treatment by both Algabon and Bonamid (Figure. 3B). Generally, there was a significant increase in the shoot and root biomass and water content of NSC plants pre-treated with Bonamid. Also, the application of Bonamid resulted in higher root/shoot biomass, which is the result of increased root growth and is consistent with root density (Figure 3. C). Similarly, the increase in dry biomass, root density and RWC of the plants sprayed with Bonamid compared to the Algabon treatment and control plants was most pronounced at $300 \mathrm{mM} \mathrm{NaCl}$ (Figure 3. C), and pre-treatment with Bonamid mitigated NaCl-induced growth prevention in P. distans (Figure 3. B).

In this study, we observed a composition-dependent effect of biostimulants in diminishing the effects of $\mathrm{NaCl}$ stress, so that Bonamid was more effective than Algabon. In most plants, salinity stress prevents growth and development. One of the primitive response of plants to salinity is inhibition of shoot and root growth. The effects of salinity on alteration in growth might be attributed to changes in water and ion absorption by the roots, production of hormonal signals that exchange messages to the shoot, and changes in gene expression patterns. Typically, when glycophytes are exposed to salinity stress, shoot growth is more affected than roots, leading to the enhance of root/shoot ratio (Kravchik and Bernstein 2013). However, the salinity-induced root growth response in halophyte plants may be different (Flowers and Colmer 2008).

Several studies have reported the affirmative effect of biostimulants on plant growth in a wide range of compounds such as seaweed extract, protein hydrolysis and humic acids under stress (Lucini et al. 2015; Latef et al. 2017; Saidimoradi et al. 2019). The application of seaweed extract- and protein hydrolysates-derived biostimulants might supply defence opposed to salinity stress in plants. Latef et al. (2017) suggested that foliar applications of two seaweed extracts improved plant growth and photosynthetic pigments of Cicer arietinum under saline soil condition. Also, exopolysaccharide extracts from Dunaliella salina diminished the salinity stress and alleviated the decrease in dry weight of the plant's shoot and root systems in Solanum lycopersicum (Arroussi et al. 2018). Lucini et al. (2015) also demonstrated that foliar application of LISIVEG ${ }^{\circledR}$ (the plant-derived protein hydrolysate) biostimulant increased fresh yield, dry biomass and root dry weight of Lactuca sativa grown under salinity conditions. It is well known protein hydrolysates-derived biostimulant that play an important role in stimulation of growth, increase of yield and alleviation of the impact of salinity stress on crops, through the modulation of plant molecular and physiological processes. Protein hydrolysates-derived biostimulants directly influence on plant growth by the induction of carbon and nitrogen metabolisms, as well as regulation of $\mathrm{N}$ uptake and by interfering with hormonal activities, leading to the stimulation of root and shoot growth, and thus crop productivity (Colla et al. 2017).

Foliar and root applications of protein hydrolysates-derived biostimulants have been demonstrated to increase the uptake and use efficiency of both macro and micronutrients (Colla et al. 2015). Modifications of root density in protein hydrolysate-treated plants may be involved to improve the efficiency of water and nutrient uptake, thus promoting yield production (Colla et al. 2015). Subbarao et al. (2015) also indicated a positive effect of protein hydrolysate on enhancement of root and shoot growth, and found that soil application was more effective than foliar application. Similar results were obtained by Popko et al., (2018), who recommended foliar application of amino acids-based biostimulantsfor an efficient agricultural production of winter wheat. In our study, the Bonamid pre-treatment mediated- 
growth promotion effect on $P$. distans seedlings under salinity stress was simply explained by higher biomass and density of roots that led to the enhancement of the efficiency of water and nutrient (especially N) uptake.

Salinity stress decreased total chlorophyll content in control plants, whilst foliar spray of two biostimulants enhanced chlorophyll content and diminished detrimental impacts of salinity. Application of biostimulants plays an important role in enhancing chlorophyll content (Latef et al. 2017; Saidimoradi et al. 2019). Colla et al. (2014) also showed that a commercial plant-derived PH (Trainer) induced chlorophyll synthesis by the increasing of leaf nitrogen content. Generally, there was a significant increase in total chlorophyll in plants pre-treated with Bonamid under SC. Protein hydrolysate can also help plants to retain photosynthetic activity under stress conditions.

These results are in agreement with those of Lucini et al. (2015) and Di Mola et al., (2021) who stated that application of a plant-derived protein hydrolysate increased photochemical activity (Fv/Fm) in lettuce and hemp, respectively, grown under saline conditions. This factor ensures better photosynthetic metabolism and thus improves plant performance. Foliar spray of $P$. distans seedlings with two biostimulants enhanced carotenoid content in NSC. It has been shown that biostimulants are effective in increasing production of several classes of secondary metabolites such as carotenoids, which are involved in crop quality and stress response. Foliar application of seaweed extract from Ecklonia maxima increased chlorophylls and carotenoids concentrations in Brassica oleracea (Rengasamy et al. 2016). Application of an amino acid-derived biostimulant had positive effects on carotenoid content in two varieties of carrot (Grabowska et al. 2012). In general, under salinity conditions, the carotenoid content was unchanged in plants pre-treated with two biostimulants (Figure 4B), likely due to the great enhance in biomass produced by biostimulants, which in turn might dilute some of the compounds in the tissues.

\subsection{Pre-treatment of biostimulants significantly impacted compatible solutes in P. distans seedling under salinity stress}

The accumulation of compatible solutes, including proline, soluble sugar and glycine betaine was reported in halophytes plants likely for the modulation of osmotic signalling pathways in vacuoles, as well as stabilization of membranes and act as ROS scavengers (Sharma et al. 2019). At $300 \mathrm{mM}$ of $\mathrm{NaCl}$, proline, glycine betaine and soluble sugar content of roots and shoots enhanced in control plants of $P$. distans. Under salinity conditions, foliar spray of two biostimulants increased proline and soluble sugar concentrations of roots and shoots compared with their counterparts grown under NSC that diminished detrimental impacts of salinity in P. distans seedling. Previous studies also showed that foliar application of seaweed extract- and protein hydrolysates-derived biostimulants improved salt stress amelioration in plants by enhancing proline, soluble sugar and glycine betaine contents (Ertani et al. 2013; Arroussi et al. 2018; Latef et al. 2017). Osmotic regulation in stressed plants is highly dependent on soluble sugars, and in glycophytic plants, more than $50 \%$ of the maintenance of osmotic regulation under salinity stress is related to the production of soluble sugars. The important roles of carbohydrates in the alleviation of salinity-induced responses involves osmoprotection, scavenging of ROS and carbon storage. The enhancement of reducing sugars under salinity stress has been previously observed in various plants (Kerepesi and Galiba 2000). The upregulation genes associated with osmotic regulation has been also reported in halophytic plant of Spartina alterniflora under salinity stress (Baisakh et al. 2006).

Biostimulants produced based on protein hydrolysates and amino acids showed quality improvement in one cultivar of carrot by increasing soluble sugar content (Grabowska et al. 2012). Higher sugar level in plants treated with biostimulants have been detected in different species, together with higher carotenoid and chlorophyll contents, photosynthetic rates, stomatal conductance, total protein, phenols, ascorbic acid, as well as growth-promoting hormones (Abbas 2013; Abdalla 2013; Martinez Esteso et al. 2016; Arroussi et al. 2018). After the exposure of Bonamid-pre-treated plants under salinity conditions, we observed the reduction of glycine betaine in the leaves of $P$. distans. Similar to our results, some researchers revealed that by the application of biostimulants, the compatible solutes decreased in salinitystressed plants (Aydin et al. 2012; Jarošová et al. 2016). One possible reason for this observation in plants pre-treated 
with Bonamid is the more participation of glycine betaine in the moderation of deleterious impacts of salinity in $P$. distans. Glycine-betaine is likely the major compatible solute other than proline. Application of a seaweed-based biostimulant had the effect of glycine betaine synthesis in spinach (Fan et al. 2011). The improvement in salinity tolerance in Bonamid-pre-treated plants may be attributed to the ingredients of the Bonamid (containing amino acid (85\%)), which could induced the plant's metabolism to biosynthesis of compatible solutes and these protective compounds increase the plant potential to exclude $\mathrm{Cl}^{-}$ions.

\subsection{Pre-treatment of biostimulants significantly impacted antioxidants potential in P. distans seedling under salinity stress}

Besides the accumulation of compatible solutes, to fight against salinity-induced oxidative stress, plants increase the biosynthesis and accumulation of non-enzymatic antioxidant compounds, particularly metabolic pathways associated with polyphenolic antioxidants biosynthesis (Cheynier et al. 2013). Under salinity stress, total phenolic compounds and radical scavenging activity increased in control plants of $P$. distans, also foliar spray of two biostimulants increased the antioxidant potential and total phenolic compounds compared with their counterparts grown under NSC and moderated detrimental impacts of salinity. Induction of oxidative damage under salinity stress through forming ROS has been reported in halophytes plants (Ellouzi et al. 2011; Bose et al. 2014). Hence, halophytes plants are able to synthesize nonenzymatic antioxidants such as total phenolic compounds under salinity conditions (He et al. 2020; He et al. 2021). Hsouna et al. 2020 revealed enhancement of polyphenol compounds in the leaves of the halophyte Lobularia maritima when exposed to saline conditions that might be related to the up-regulation of phenylalanine ammonia-lyase activity. Many quality characteristics of plants are linked to secondary metabolites, like polyphenols. These compounds are free radical scavengers, and may preserve plants against oxidative stress. Hence, interaction of biostimulants with the flavonoid metabolism can synergistically strengthen their effects. Enhancement in polyphenols contents of plant tissues by the biostimulant application has been shown in different glycophyte plants (Gurav and Jadhav 2013; Elansary et al. 2016). However, the research on the effects of biostimulants on the levels of phenolic compounds in halophyte plants has been very limited. Kaluzewicz et al. (2017) reported that the application of amino acid-based biostimulants and Ascophyllum nodosum filtrate increased the total phenolic content, sinapic acid content, as well as quercetin content in Brassica oleracea seedlings. According to the results of this study, Latef et al., (2017) and Arroussi et al. (2018), demonstrated that the foliar spray of seaweed extract-based biostimulant enhanced the levels of phenolic compounds in chickpea and tomato plants, respectively, under salinity stress, thus leading to salt stress alleviation. Amino acids-based biostimulants enhanced the activity of phenylalanine ammonia-lyase, which is the first step in phenylpropanoid pathway and starting point for secondary metabolics pathways and production of a wide range of phenolic compounds, such as flavonoids, anthocyanins, plant hormones, phytoalexins and lignins (du Jardin et al. 2020). In our study, biostimulantsmediated induction of phenylpropanoid compounds as well as the antioxidant capacity of plants under salinity stress would increase their health-related characteristics, leding to maintaining a high level of chemical defence capability and, in turn, better efficiency in respect of plant growth. Generally, a better status of the plants pre-treated with Bonamid, as well as potentially higher tolerance to salinity (Fig 3B) due to the presence of phenolic compounds, was also shown by the higher content of proline and proteins, indicative of the more magnitude of metabolic activity in plants treated with the biostimulant.

\subsection{Pre-treatment of biostimulants significantly influenced protein and nitrogen percentage of shoots and roots in P. distans seedlings under salinity stress}

Based on the results, root and shoot protein and nitrogen contents of $P$. distans can be affected by applying foliar spray of biostimulants under NSC. The highest content of proteins and nitrogen was found in roots and shoots of Bonamid pre-treated plants. Application of biostimulants have a major role in enhancing protein and nitrogen content (Ertani et al. 2013; Colla et al. 2014; Lucini et al. 2015). Abiotic stresses such as salinity increase ROS production and by upsetting

Page $13 / 25$ 
redox balance, cause oxidative damage to organic molecules such as proteins, lipids, carbohydrates, and DNA. Under salinity stress, the protein content decreased in all pre-treated plants compared with their counterparts grown under NSCs, however the maximum content of proteins in roots and shoots was detected in Bonamid pre-treated $P$. distans. Salinity stress could also alter several metabolic processes in plants, in particular, photosynthesis, respiration, phytohormone regulation, protein biosynthesis and nitrate assimilation (Colla et al. 2010). It generally leads to a decrease of production and to the lower quality of the final product, due to an inhibition of leaves and roots growth (Bulgari et al. 2019). To confirm the effects eliciting from the applications of biostimulants, Lucini et al. (2015) showed that foliar application of a hydrolysate biostimulant increased yield and dry weight in lettuce plants, leading to resistance to salinity stress through the improvement of nitrogen metabolism and an increase of the Fv/Fm-ratio efficiency. It has been also reported that application of seaweed extract-based biostimulant mitigated salinity-mediated protein reduction in tomato plants grown under different $\mathrm{NaCl}$ levels, through the activation of various metabolic pathways (Arroussi et al. 2018). However, abiotic stresses such as salinity increase nitrogenous compounds such as proline and soluble proteins in the plant. These proteins are essential for all plant's physiological processes including plant growth. Proteins produced under salinity stress in plants may be used as a source of nitrogen after stress. Since protein synthesis depends on the nitrate assimilation, it is obvious that the reduction of nitrogen assimilation under salinity stress can be the cause of the decrease in the protein content.

\subsection{Pre-treatment of biostimulants significantly impacted $\mathrm{Na}^{+}, \mathrm{K}^{+}, \mathrm{K}^{+} / \mathrm{Na}^{+}$and antiporters gene expression of shoots and roots in P. distans seedling under salinity stress}

It has been shown that a disruption of $\mathrm{Na}^{+}$and $\mathrm{K}^{+}$homeostasis in cells followed by ion toxicity, adversely influences some major processes such as growth, photosynthesis, and development (Deinlein et al. 2014) and in both glycophyte and halophyte plants, sensitivity of cytosolic enzymes in front of salinity is similar. Hence, in all plants, maintaining cellular homeostasis of $\mathrm{Na}^{+}$and $\mathrm{K}^{+}$is crucial allowing plants to survive and grow under salt stress conditions (Cuin et al. 2011).

Our results showed that foliar spray of $P$. distans plants with two biostimulants reduced salinity-induced $\mathrm{Na}^{+}$ accumulations in roots and shoots. Salinity induced a reduction of $\mathrm{K}^{+}$content of roots of $P$. distans; however, in the biostimulants pre-treated seedlings, it significantly compensated the negative impacts of salinity and enhanced $\mathrm{K}^{+}$ content in roots and shoots. Similarly, Latef et al. (2017) suggested that foliar applications of two seaweed extracts decreased the extent of $\mathrm{Na}^{+}$accumulation and maintained higher $\mathrm{K}^{+}$levels of Cicer arietinum under salinity stress. Furthermore, Wu et al., (2021) demonstrated that $\mathrm{Na}^{+}$contents of roots in cucumber increased significantly under salinity stress; however, after foliar spray of 5-aminolevulinic acid (ALA), the $\mathrm{Na}^{+}$content in the roots decreased significantly. Osmotic adjustments play important role in plant resistance under salt stress, which include the intake of inorganic solutes from the soil to help the maintenance of leaves' turgor. Osmotic adjustments have been observed for the improvement of osmoregulation and resistance to salinity in halophyte plants (Jones and Gorham 2002; Hariadi et al. 2011). The effects of biostimulants in plant resistance against salinity can be attributed to the improvement of the osmotic adjustment by the accumulation of osmotic metabolites and the compartmentalization of salts in vacuoles. Our data indicated that application of biostimulants probably affected the mechanisms of uptake and translocation of ions in roots and shoots under both conditions. These biostimulant's beneficial effects includes the inhibition of $\mathrm{Na}^{+}$ accumulations and improvement of $\mathrm{K}^{+}$uptake in the leaves, leading to an increases $\mathrm{K}^{+} / \mathrm{Na}^{+}$ratio of roots and shoots (Table. 3).

On the basis of phytoremediation potential (shoot and total) of Bonamid pre-treated $P$. distans seedlings (Figure. 6) that is the best criterion for comparison with the other pre-treatments, we decided to investigate this criterion in Bonamid pretreated $P$. distans seedlings under both conditions at the molecular level, through determination of genes expression

Page $14 / 25$ 
profile of SOS1: plasma membrane $\mathrm{Na}^{+} / \mathrm{H}^{+}$and $\mathrm{NHX} 1$ : tonoplast $\mathrm{Na}^{+} / \mathrm{H}^{+}$antiporters. The mechanisms accepted by plants surviving in saline conditions include a balance between influx and efflux of $\mathrm{Na}^{+}$, either back into the apoplast across the plasma membrane or the tonoplast into the vacuole. In halophyte plants, the developed tolerance mechanisms like compartmentalization of ions in vacuoles are performed by $\mathrm{Na}^{+} / \mathrm{H}^{+}$antiporter (NHX1) and salt extrusion through antiporter (SOS1) located in the plasma membrane (Wang et al. 2007; Hamed et al. 2013). The presence of $\mathrm{Na}^{+} / \mathrm{H}^{+}$antiporter in the plasma membrane of plants is crucial for their growth under high salinity as it removes toxic $\mathrm{Na}^{+}$from the cytoplasm. Salt stress increases the gene expression of SOS genes in Arabidopsis (Oh et al. 2009), Kochia scoparia (Fahmideh and Fooladvand 2018) and sugarcane (Brindha et al. 2021). Several reports indicate that NHX overexpression confers salinity tolerance in a wide range of plant species (Brini et al. 2007), tomato (Zhang and Blumwald 2001) and cotton (He et al. 2007).

Exposure of $P$. distans seedlings under salinity increased the expression of SOS1and NHX1 in roots and leaves. In halophytic plants as opposed to glycophytes, accumulation of $\mathrm{Na}^{+}$in vacuoles and the regulation of activity of $\mathrm{Na}^{+} / \mathrm{H}^{+}$ exchanger (NHX1) have been seen under salinity conditions. For example, Wang et al. (2009) showed that the significant mechanism of halophytic species of $P$. tenuiflora to succeed in dealing with $\mathrm{NaCl}$ was excreting $\mathrm{Na}^{+}$. Also, Zhang et al., (2017) showed that SOS1, HKT1;5, and NHX1 synergistically regulate $\mathrm{Na}^{+}$homeostasis by controlling $\mathrm{Na}^{+}$transport systems at $P$. tenuiflora plant under both lower and higher salt conditions. In accordance with the results of the present study, the upregulation of NHX of Suaeda salsa (Qiu et al. 2007) and two antiporters of SOS1 and NHX in Kochia scoparia (Fahmideh and Fooladvand 2018) under salinity stress have also been reported.

It has been shown that biostimulants can elicit plant response to environmental stress, thus activating genes associated with signalling pathways related to stress response (Trevisan et al. 2017; Jithesh et al. 2019). In this regard, it is believed that the genes expression of $\mathrm{Na}^{+} / \mathrm{H}^{+}$transporters generally increases by exogenously application of biostimulants. The foliar spray of 5-aminolevulinic acid (ALA) significantly upregulated the transcriptional level of SOS1 and NHX1 under normal and salinity conditions (Wu et al. 2021). This indicated that ALA application can improve the compartmentation of $\mathrm{Na}^{+}$into vacuoles and enhance the salt resistance of cucumber seedlings. Similar to our results, stimulation of the expression of SOS1 in Arabidopsis with a commercially biostimulant (BC204) treatment (Loubser and Hills 2020) and the expression of vacuolar $\mathrm{Na}^{+} / \mathrm{H}^{+}$exchanger ( $\mathrm{NHX} 1$ gene) with silicon treatment have been reported in cucumber (Gou, 2020). On the contrary, Jithesh et al. (2018) found that the treatment of sos1 Arabidopsis mutant with Ascophyllum nodosum extract in media containing $75 \mathrm{mM} \mathrm{NaCl}$ did not reverse the lethality of salt. The results of our study showed that foliar application of Bonamid increased gene expression of SOS1 in roots, which coincided with a reduction of $\mathrm{Na}^{+}$ concentration in roots of Bonamid-pre-treated plants probably due to SOS1 proteins function that acts in loading of $\mathrm{Na}^{+}$ into the xylem of roots for regulating $\mathrm{Na}^{+}$release to the leaves and contribution in osmotic adjustment. Furthermore, foliar application of Bonamid enhanced the gene expression of NHX1 under $300 \mathrm{mM} \mathrm{NaCl}$, which suggested that the sequestration of $\mathrm{Na}^{+}$to the vacuole increased to reduce $\mathrm{Na}^{+}$toxicity in the cytoplasm.

\section{Conclusion}

One of the important approaches for the improvement of salinity stress tolerance in plants is the application of biostimulants. However, the effectiveness of biostimulants depends on their penetration into the plant tissue; hence, the selection of a suitable biostimulant is crucial as the efficiency can vary considerably between species. This research studied the effects of the pre-treatment of two biostimulants (seaweed extract-derived and amino acid-derived biostimulants) on $P$. distans seedling under salinity tolerance. The results obtained in the present study show the beneficial effects of the pre-treatments of two biostimulants on $P$. distans seedlings under non salinity stress conditions with respect to increasing plant biomass, photosynthetic pigments, $\mathrm{K}^{+}$content, the content of proteins and nitrogen 
percentage. The results suggested that foliar spray of Bonamid could considerably diminish $\mathrm{NaCl}$-caused stress on $P$. distans seedlings, probably due to higher accumulation of shoot biomass, photosynthetic pigments, $\mathrm{K}^{+} / \mathrm{Na}^{+}$ratio, protein and $\mathrm{N}$ content and phytoremediation potential. Also, foliar spray with Bonamid amplified the expression of SOS1 and $\mathrm{NHX} 1$ in the roots and leaves, respectively, under salinity stress, that likely led to the loading of $\mathrm{Na}^{+}$into the xylem and reduction of $\mathrm{Na}^{+}$content in the cytoplasm and contribution in osmotic adjustment. Considering the failure of pretreatment of $P$. distans seedlings as foliar spray with Algabon in overcoming salinity stress, it seems that the application method or proposed concentration for this biostimulant is not appropriate and should probably be used in soil. Collectively, it could be concluded that, intensification of osmotic adjustment by the accumulation of osmotic metabolites and the compartmentalization of salts in vacuoles in pre-treated plants with amino acid-derived biostimulant (Bonamid) can diminish the $\mathrm{NaCl}$-induced deleterious effects in $P$. distans seedlings.

\section{Abbreviations}

NSC, Non- salinity condition; RSA, Radical Scavenging Activity; ROS, Reactive oxygen species; RWC, relative water content; SC, Salinity condition; STI, Salt tolerance index; PP, Phytoremediation potential.

\section{Declarations}

\section{Ethics approval and consent to participate}

Not applicable.

\section{Consent for publication}

Not applicable.

\section{Availability of data and materials}

Agree.

\section{Competing interests}

The authors declare that they have no competing interests.

\section{Funding:}

Not applicable.

\section{Authors' contributions}

Conceived and designed the experiments: Leila Shabani, Mohammad R. Sabzalian. Performed the experiments: Saeed Hosseini. Analyzed the data: Saeed Hosseini, Leila Shabani, Shima Gharibi. Wrote the paper: Leila Shabani. Edited the manuscript: Leila Shabani, Mohammad R. Sabzalian.

\section{Acknowledgments:}

The authors are grateful for the grant from Shahrekord University, Iran grant number: 98GRD1M1032.

\section{References}


1. Abbas SM (2013) The influence of biostimulants on the growth and on the biochemical composition of Vicia faba CV. Giza 3 beans. Rom Biotechnol Lett 18:8061-8068

2. Abdalla MM (2013) The potential of Moringa oleifera extract as a biostimulant in enhancing the growth, biochemical and hormonal contents in rocket (Eruca vesicaria subsp. sativa) plants. Int J Plant Physiol Biochem 5:42-49

3. Abdelhamid MT, Raafat REM, Darwish DS, Abdalla MMF, Oba S, Ragab R, Sabagh AEL, Kholy MHE, Omer E (2019) Mechanisms of seed priming involved in salt stress amelioration. In: Priming and Pretreatment of Seeds and Seedlings (Springer)

4. Akhani H (2006) Biodiversity of halophytic and sabkha ecosystems in Iran. In: Sabkha ecosystems (Springer)

5. Arroussi HEL, Benhima R, Elbaouchi A, Sijilmassi B, Mernissi NEL, Aafsar A, Meftah-Kadmiri I, Bendaou N, Smouni A (2018) Dunaliella salina exopolysaccharides: a promising biostimulant for salt stress tolerance in tomato (Solanum lycopersicum). J Appl Phycol 30:2929-2941

6. Aydin A, Canan K, Metin T (2012) Humic acid application alleviate salinity stress of bean (Phaseolus vulgaris L.) plants decreasing membrane leakage. Afr J Agric Res 7:1073-1086

7. Baisakh N, Prasanta KS, Neil PP (2006) cDNA-AFLP analysis reveals differential gene expression in response to salt stress in a halophyte Spartina alterniflora Loisel. Plant Sci 170:1141-1149

8. Barrs H, Weatherley $\mathrm{P}$ (1962) A re-examination of the relative turgidity technique for estimating water deficits in leaves. Aust J Biol Sci 15:413-428

9. Bartels D, Sunkar R (2005) Drought and salt tolerance in plants. CRC Crit Rev Plant Sci 24:23-58

10. Bose J, Rodrigo-Moreno A, Shabala S (2014) ROS homeostasis in halophytes in the context of salinity stress tolerance. J Exp Bot 65:1241-1257

11. Brindha C, Vasantha S, Raja AK, Tayade AS (2021) Characterization of the Salt Overly Sensitive pathway genes in sugarcane under salinity stress. Physiol Plant 171:677-687

12. Brini F, Hanin M, Mezghani I, Berkowitz GA, Masmoudi K (2007) Overexpression of wheat Na+/H+ antiporter TNHX1 and $\mathrm{H}+$-pyrophosphatase TVP1 improve salt-and drought-stress tolerance in Arabidopsis thaliana plants. J Exp Bot 58:301-308

13. Bulgari R, Cocetta G, Trivellini A, Vernieri P, Ferrante A (2015) Biostimulants and crop responses: a review. Biol Agric Hortic 31:1-17

14. Bulgari R, Franzoni G, Ferrante A (2019) Biostimulants application in horticultural crops under abiotic stress conditions. Agronomy 9:306

15. Cheynier V, Comte G, Davies KM, Lattanzio V, Martens S (2013) Plant phenolics: recent advances on their biosynthesis, genetics, and ecophysiology. Plant Physiol Biochem 72:1-20

16. Colla G, Hoagland L, Ruzzi M, Cardarelli M, Bonini P, Canaguier R, Rouphael Y (2017) Biostimulant action of protein hydrolysates: unraveling their effects on plant physiology and microbiome. Front Plant Sci 8:2202

17. Colla G, Rouphael Y, Canaguier R, Svecova E, Cardarelli M (2014) Biostimulant action of a plant-derived protein hydrolysate produced through enzymatic hydrolysis. Front Plant Sci 5:448

18. Colla G, Rouphael Y, Di Mattia E, El-Nakhel C, Cardarelli M (2015) Co-inoculation of Glomus intraradices and Trichoderma atroviride acts as a biostimulant to promote growth, yield and nutrient uptake of vegetable crops. J Sci Food Agric 95:1706-1715

19. Colla G, Rouphael Y, Leonardi C, Bie Z (2010) Role of grafting in vegetable crops grown under saline conditions. Sci Hortic 127:147-155

20. Cuin TA, Bose J, Stefano G, Jha D, Tester M, Mancuso S, Shabala S (2011) Assessing the role of root plasma membrane and tonoplast $\mathrm{Na}+/ \mathrm{H}+$ exchangers in salinity tolerance in wheat: in planta quantification methods. Plant

Page $17 / 25$ 
Cell Environ 34:947-961

21. Dashtebani F, Hajiboland R, Aliasgharzad N (2014) Characterization of salt-tolerance mechanisms in mycorrhizal (Claroideoglomus etunicatum) halophytic grass, Puccinellia distans. Acta Physiol Plant 36:1713-1726

22. Deinlein U, Stephan AB, Horie T, Luo W, Xu G, Schroeder JI (2014) Plant salt-tolerance mechanisms. Trends Plant Sci 19:371-379

23. Desoky ESM, Merwad ARM, Rady MM (2018) Natural biostimulants improve saline soil characteristics and salt stressed-sorghum performance. Commun Soil Sci Plant Anal 49:967-983

24. Dewan ML, Famouri J (1964) The soils of Iran. FAO, Rome

25. Di Stasio E, James Van Oosten M, Silletti S, Raimondi G, dell'Aversana E, Carillo P, Maggio A (2018) Ascophyllum nodosum-based algal extracts act as enhancers of growth, fruit quality, and adaptation to stress in salinized tomato plants. J Appl Phycol 30:2675-2686

26. Du Jardin P (2015) Plant biostimulants: definition, concept, main categories and regulation. Sci Hortic 196:3-14

27. du Jardin P, Xu L, Geelen D (2020) Agricultural Functions and Action Mechanisms of Plant Biostimulants (PBs) an Introduction. In: Geelen D, Xu L (eds) The Chemical Biology of Plant Biostimulants. John Wiley \& Sons Ltd, pp 1-30

28. Elansary HO, Norrie J, Ali HM, Salem MZM, Mahmoud EA, Yessoufou K (2016) Enhancement of Calibrachoa growth, secondary metabolites and bioactivity using seaweed extracts. BMC Complement Altern Med 16:1-11

29. Ellouzi H, Ben Hamed K, Cela J, Munné-Bosch S, Abdelly C (2011) Early effects of salt stress on the physiological and oxidative status of Cakile maritima (halophyte) and Arabidopsis thaliana (glycophyte). Physiol Plant 142:128143

30. Ertani A, Schiavon M, Muscolo A, Nardi S (2013) Alfalfa plant-derived biostimulant stimulate short-term growth of salt stressed Zea mays L. plants. Plant Soil 364:145-158

31. Evelin H, Devi TS, Gupta S, Kapoor R (2019) Mitigation of salinity stress in plants by arbuscular mycorrhizal symbiosis: current understanding and new challenges. Front Plant Sci 10:470

32. Fahmideh L, Fooladvand Z (2018) Isolation and semi quantitative PCR of Na+/H+ antiporter (SOS1 and NHX) genes under salinity stress in Kochia scoparia. Biol Proced Online 20:1-9

33. Fan D, Hodges DM, Zhang J, Kirby CW, Ji X, Locke SJ, Critchley AT, Prithiviraj B (2011) Commercial extract of the brown seaweed Ascophyllum nodosum enhances phenolic antioxidant content of spinach (Spinacia oleracea L.) which protects Caenorhabditis elegans against oxidative and thermal stress. Food Chem 124:195-202

34. Fasciglione G, Casanovas EM, Quillehauquy V, Yommi AK, Goni MG, Roura SI, Barassi CA (2015) Azospirillum inoculation effects on growth, product quality and storage life of lettuce plants grown under salt stress. Sci Hortic 195:154-162

35. Flowers TJ, Colmer TD (2008) Salinity tolerance in halophytes. New Phytol 179:945-963

36. Flowers TJ, Munns R, Colmer TD (2015) Sodium chloride toxicity and the cellular basis of salt tolerance in halophytes. Ann Bot 115:419-431

37. Gou TY, Su Y, Chen XH, Zhu YX, Gong HJ (2020) Silicon upregulates NHX1 expression to enhance Na+ partitioning into vacuoles in leaf mesophyll cells of cucumber under salt stress. J Plant Nutr Fertil 26:1923-1934

38. Goudarzi M, Pakniyat H (2008) Evaluation of wheat cultivars under salinity stress based on some agronomic and physiological traits. JASR 4:35-38

39. Grabowska A, Kunicki E, Sekara A, Kalisz A, Wojciechowska R (2012) The effect of cultivar and biostimulant treatment on the carrot yield and its quality. Veg Crop Res Bull 77:37

40. Gurav RG, Jadhav JP (2013) A novel source of biofertilizer from feather biomass for banana cultivation. Environ Sci Pollut Res 20:4532-4539 
41. Hamed KB, Ellouzi H, Zribi Talbi O, Hessini K, Slama I, Ghnaya T, Munné Bosch S, Savouré A, Abdelly C (2013) Physiological response of halophytes to multiple stresses. Funct Plant Biol 40:883-896

42. Hariadi Y, Marandon K, Tian Y, Jacobsen SE, Shabala S (2011) lonic and osmotic relations in quinoa (Chenopodium quinoa Willd.) plants grown at various salinity levels. J Exp Bot 62:185-193

43. He C, Shen G, Pasapula V, Luo J, Venkataramani S, Qui X, Kuppu S, Kornyeyev D, Holaday AS, Auld D (2007) Ectopic expression of AtNHX1 in cotton (Gossypium hirsutum L.) increases proline content and enhance photosynthesis under salt stress conditions. J Cotton Sci 11:266-274

44. He J, Chua EL, Qin L (2020) Drought does not induce crassulacean acid metabolism (CAM) but regulates photosynthesis and enhances nutritional quality of Mesembryanthemum crystallinum. Plos One 15:e0229897

45. He J, Koh DJQ, Qin L (2021) LED spectral quality and NaCl salinity interact to affect growth, photosynthesis and phytochemical production of Mesembryanthemum crystallinum. Funct Plant Biol. doi: 0.1071/FP20375, PMID

46. Hsouna B, Ghneim-Herrera T, Ben Romdhane W, Dabbous A, Ben Saad R, Brini F, Abdelly C, Ben Hamed K (2020) Early effects of salt stress on the physiological and oxidative status of the halophyte Lobularia maritima. Funct Plant Biol 47:912-924

47. Jarošová M, Klejdus B, Kováčik J, Babula P, Hedbavny J (2016) Humic acid protects barley against salinity. Acta Physiol Plant 38:1-9

48. Jithesh MN, Shukla PS, Kant P, Joshi J, Critchley AT, Prithiviraj B (2019) Physiological and transcriptomics analyses reveal that Ascophyllum nodosum extracts induce salinity tolerance in Arabidopsis by regulating the expression of stress responsive genes. J Plant Growth Regul 38:463-478

49. Jones GW, Gorham J (2002) Intra-and inter-cellular compartmentation of ions. In: Salinity: environment-plantsmolecules (Springer)

50. Kerepesi I, Galiba G (2000) Osmotic and salt stress-induced alteration in soluble carbohydrate content in wheat seedlings. Crop Sci 40:482-487

51. Kravchik M, Bernstein N (2013) Effects of salinity on the transcriptome of growing maize leaf cells point at cell-age specificity in the involvement of the antioxidative response in cell growth restriction. BMC Genom 14:1-13

52. Kulisic T, Radonic A, Katalinic V, Milos M (2004) Use of different methods for testing antioxidative activity of oregano essential oil. Food Chem 85:633-640

53. Kunicki E, Grabowska A, Sękara A, Wojciechowska R (2010) The effect of cultivar type, time of cultivation, and biostimulant treatment on the yield of spinach (Spinacia oleracea L.). Folia Hortic 22:9-13

54. Latef AAHA, Abu Alhmad MF, Abdelfattah KE (2017) The possible roles of priming with ZnO nanoparticles in mitigation of salinity stress in lupine (Lupinus termis) plants. J Plant Growth Regul 36:60-70

55. Latef AAHA, Kumar Srivastava A, Saber H, Alwaleed EA, Tran LSP (2017) Sargassum muticum and Jania rubens regulate amino acid metabolism to improve growth and alleviate salinity in chickpea. Sci Rep 7:1-12

56. Livak KJ, Schmittgen TD (2001) Analysis of relative gene expression data using real-time quantitative PCR and the $2^{-\Delta \Delta C T}$ method. Methods 25:402-408

57. Loubser J, Hills P (2020) The application of a commercially available citrus-based extract mitigates moderate $\mathrm{NaCl}-$ Stress in Arabidopsis thaliana plants. Plants 9:1010

58. Lucini L, Rouphael Y, Cardarelli M, Canaguier R, Kumar P, Colla G (2015) The effect of a plant-derived biostimulant on metabolic profiling and crop performance of lettuce grown under saline conditions. Sci Hortic 182:124-133

59. Martinez Esteso MJ, Vilella Antón MT, Sellés Marchart S, Martínez Márquez A, Botta-Català A, Dastis RP, BruMartínez R (2016) A DIGE proteomic analysis of wheat flag leaf treated with TERRA-SORB® foliar, a free amino acid high content biostimulant. J Integr OMICS 6(1):1-9

Page 19/25 
60. Masondo NA, Kulkarni MG, Finnie JF, Van Staden J (2018) Influence of biostimulants-seed-priming on Ceratotheca triloba germination and seedling growth under low temperatures, low osmotic potential and salinity stress.

Ecotoxicol Environ Saf 147:43-48

61. Oh DH, Leidi E, Zhang Q, Hwang SM, Li Y, Quintero FJ, Jiang X, Paino D'Urzo M, Lee SY, Zhao Y (2009) Loss of halophytism by interference with SOS1 expression. Plant Physiol 151:210-222

62. Porter H, Villar R (1997) The fate of acquired carbon in plants: chemical composition and construction costs. Plant Resource Allocation, Academic Press, San Diego, pp 30-72

63. Qiu N, Chen M, Guo J, Bao H, Ma X, Wang B (2007) Coordinate up-regulation of V-H+-ATPase and vacuolar $\mathrm{Na}+/ \mathrm{H}+$ antiporter as a response to $\mathrm{NaCl}$ treatment in a $\mathrm{C}_{3}$ halophyte Suaeda salsa. Plant Sci 172:1218-1225

64. Rady MM, Desoky ESM, Elrys AS, Boghdady MS (2019) Can licorice root extract be used as an effective natural biostimulant for salt-stressed common bean plants. S Afr J Bot 121:294-305

65. Rady MM, Mohamed GF (2015) Modulation of salt stress effects on the growth, physio-chemical attributes and yields of Phaseolus vulgaris L. plants by the combined application of salicylic acid and Moringa oleifera leaf extract. Sci Hortic 193:105-113

66. Rengasamy KRR, Kulkarni MG, Pendota SC, Van Staden J (2016) Enhancing growth, phytochemical constituents and aphid resistance capacity in cabbage with foliar application of eckol-a biologically active phenolic molecule from brown seaweed. New Biotechnol 33:273-279

67. Rouphael Y, De Micco V, Arena C, Raimondi G, Colla G, De Pascale S (2017) Effect of Ecklonia maxima seaweed extract on yield, mineral composition, gas exchange, and leaf anatomy of zucchini squash grown under saline conditions. J Appl Phycol 29:459-470

68. Saidimoradi D, Ghaderi N, Javadi T (2019) Salinity stress mitigation by humic acid application in strawberry (Fragaria $x$ ananassa Duch.). Sci Hortic 256:108594

69. Sharma A, Shahzad B, Rehman A, Bhardwaj R, Landi M, Zheng B (2019) Response of phenylpropanoid pathway and the role of polyphenols in plants under abiotic stress. Molecules 24:2452

70. Trevisan S, Manoli A, Ravazzolo L, Franceschi C, Quaggiotti S (2017) mRNA-sequencing analysis reveals transcriptional changes in root of maize seedlings treated with two increasing concentrations of a new biostimulant. J Agric Food Chem 65:9956-9969

71. Van Oosten MJ, Pepe O, De Pascale S, Silletti S, Maggio A (2017) The role of biostimulants and bioeffectors as alleviators of abiotic stress in crop plants. Chem Biol Technol Agric 4:1-12

72. Van Zelm E, Zhang Y, Testerink C (2020) Salt tolerance mechanisms of plants. Annu Rev Plant Biol 71:403-433

73. Wang SM, Zhang JL, Flowers TJ (2007) Low-affinity $\mathrm{Na}^{+}$uptake in the halophyte Suaeda maritima. Plant Physiol 145:559-571

74. Wu Y, Liu N, Hu L, Liao W, Tang Z, Xiao X, Lyu J, Xie J, Calderón-Urrea A, Yu J (2021) 5-Aminolevulinic Acid Improves Morphogenesis and $\mathrm{Na}+$ Subcellular Distribution in the Apical Cells of Cucumis sativus L. Under Salinity Stress. Front Plant Sci 12:404

75. Yakhin OI, Lubyanov AA, Yakhin IA, Brown PH (2017) Biostimulants in plant science: a global perspective. Front Plant Sci 7: 2049

76. Yuan F, Guo J, Shabala S, Wang B (2019) Reproductive physiology of halophytes: current standing. Front Plant Sci 9: 1954

77. Zahedi SM, Hosseini MS, Abadía J, Marjani M (2020) Melatonin foliar sprays elicit salinity stress tolerance and enhance fruit yield and quality in strawberry (Fragariax ananassa Duch.). Plant Physiol Biochem 149:313-323

78. Zhang HX, Blumwald E (2001) Transgenic salt-tolerant tomato plants accumulate salt in foliage but not in fruit. Nat Biotechnol 19:765-768

Page 20/25 


\section{Figures}
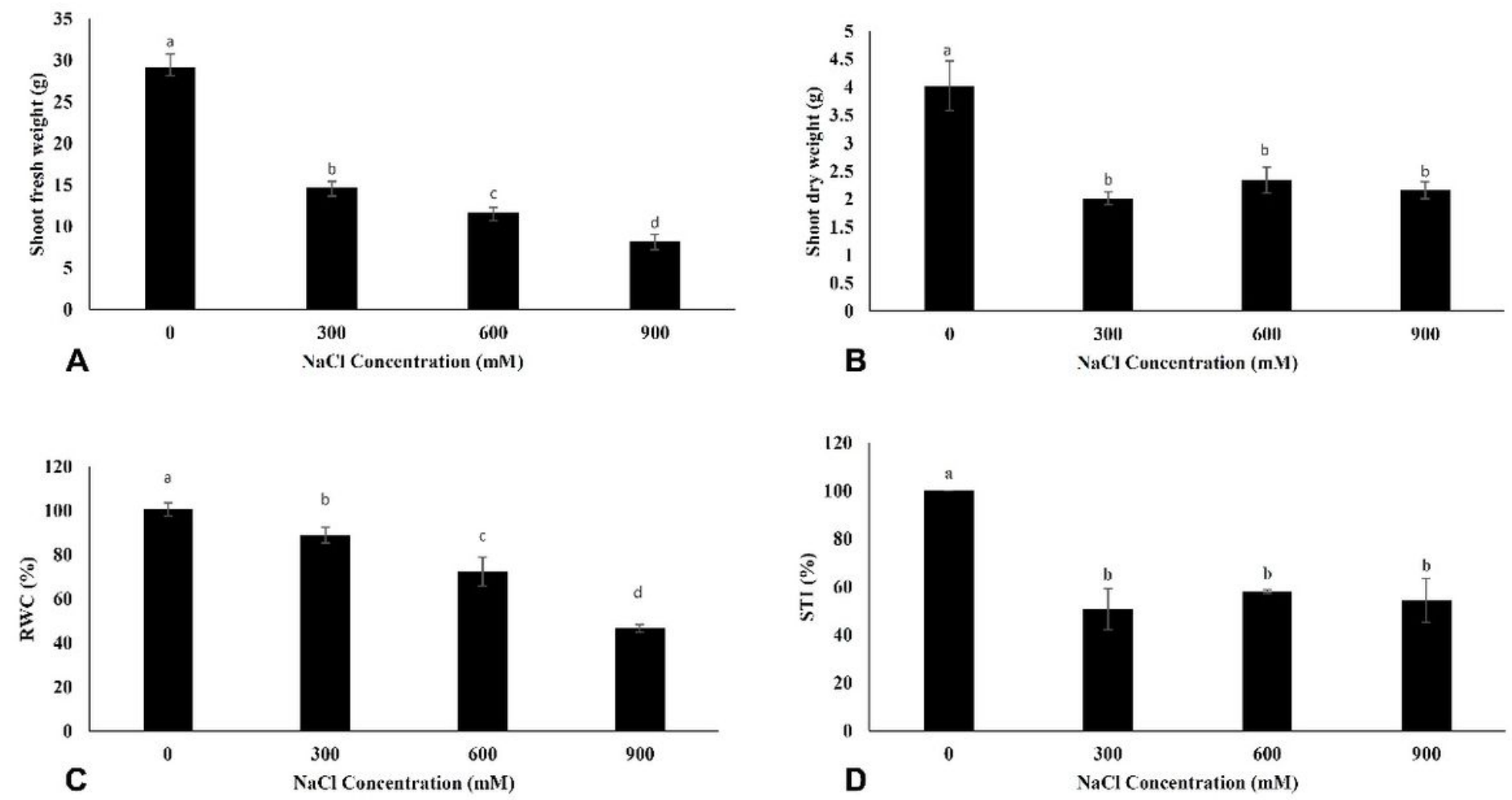

Figure 1

The effects of various concentrations of $\mathrm{NaCl}(0,300,600$, and $900 \mathrm{mM})$ on shoot fresh weight $(A)$, shoot dry weight (B) RWC (C) and salt tolerance index (STI) (D) in the seedlings of Puccinellia distans. Different letters indicate significant differences according to Duncan's tests $(p<0.05)$. 


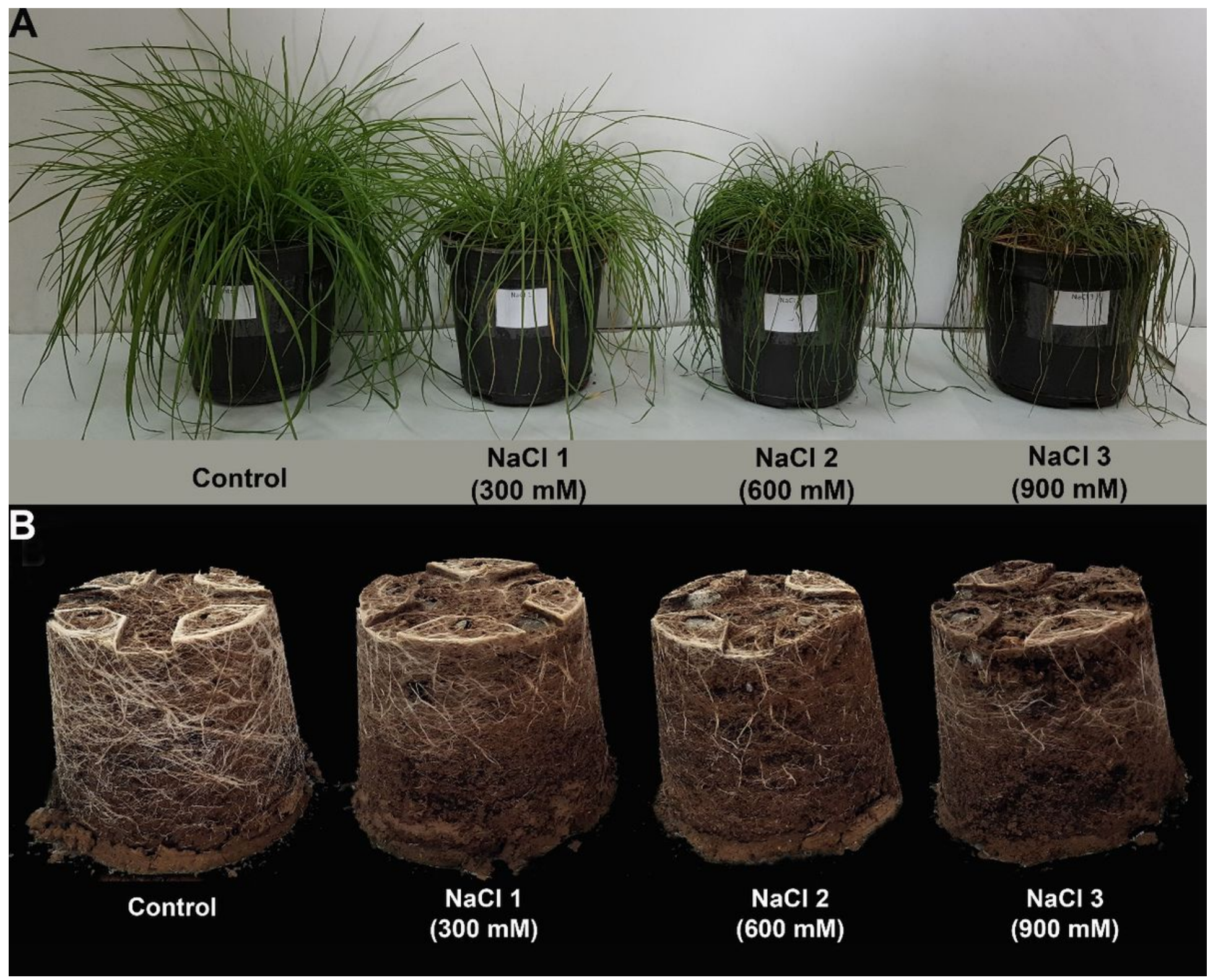

Figure 2

Image of 52-day old seedlings of Puccinellia distans under the stress of different concentrations of $\mathrm{NaCl}(\mathrm{A})$ and (B) Left to right: roots of $P$. distans seedlings grown under $0,300,600$ and $900 \mathrm{mM} \mathrm{NaCl}$. 


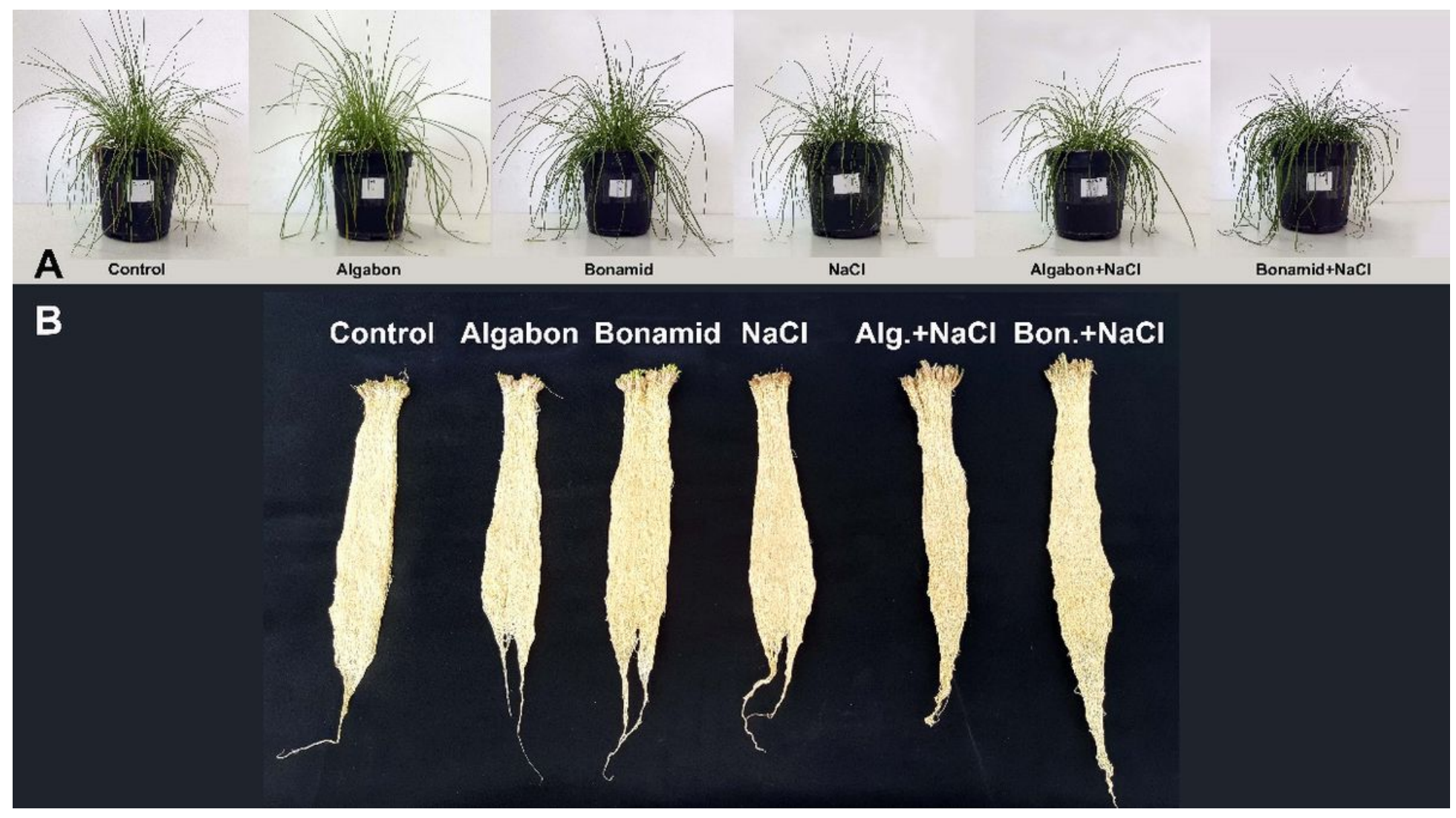

Figure 3

Representative visual image of aerial organs $(A)$ and root density $(B)$ of Puccinellia distans seedlings treated with water (control), Algabon, Bonamid, $\mathrm{NaCl}$, Algabon $+\mathrm{NaCl}$ and Bonamid $+\mathrm{NaCl}$.

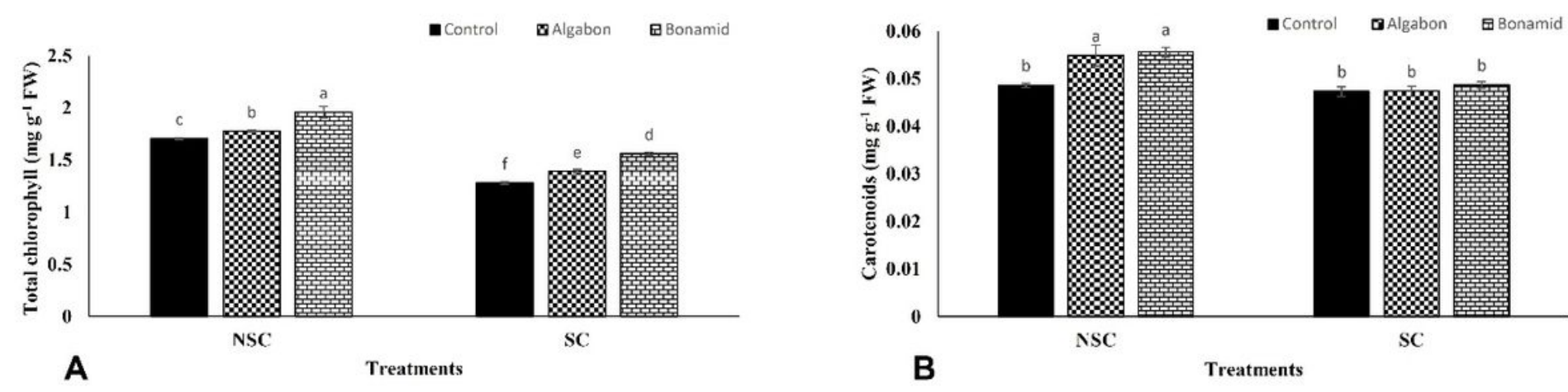

Figure 4

Chlorophyll content (A) and the amounts of carotenoid (B) in salinity condition (SC) and non-salinity condition (NSC) in Puccinellia distans exposed to foliar spraying of biostimulants. Different letters indicate significant differences according to LSD tests $(\mathrm{p}<0.05)$. 


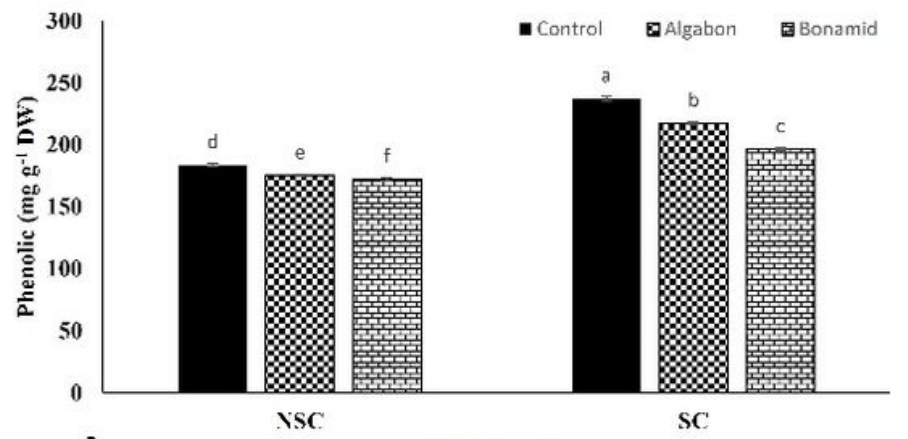

A

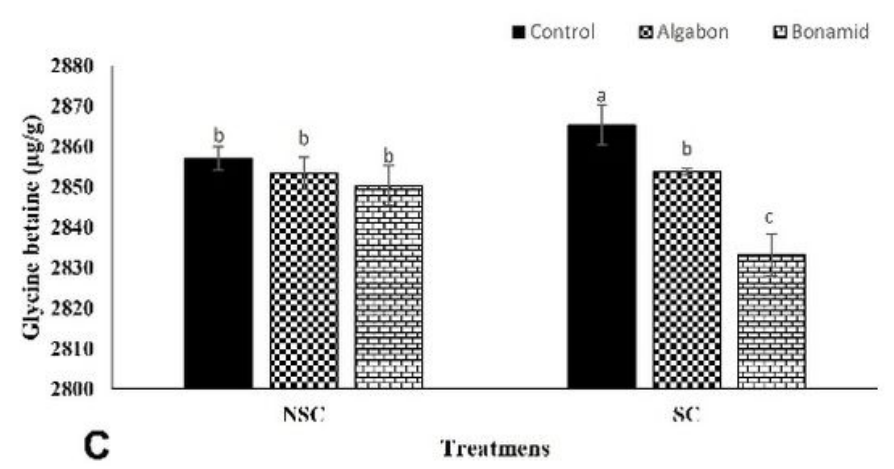

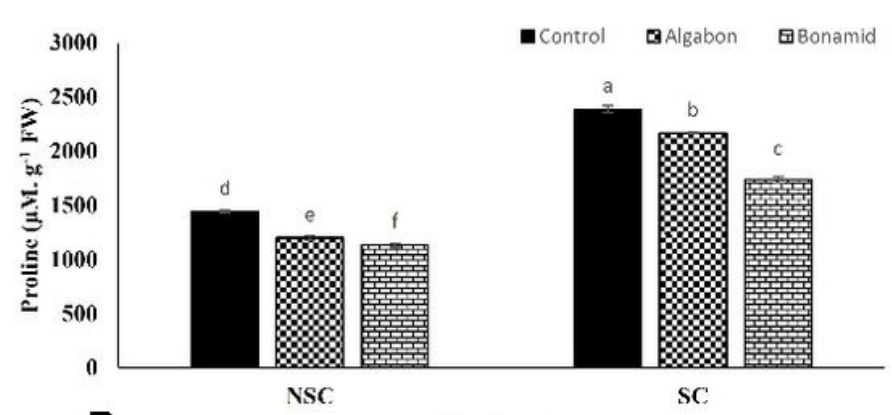

B

Treatments
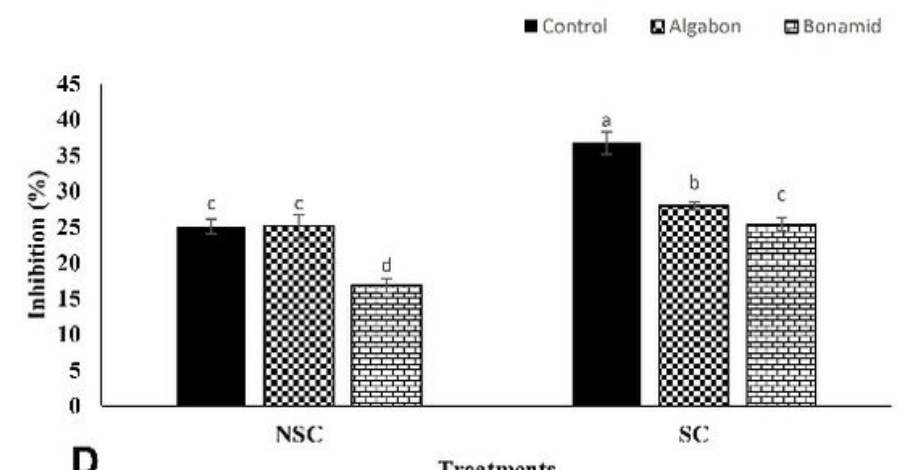

Treatments

Figure 5

Total phenolic (A), proline (B), glycine betaine (C) and RSA (D) content in salinity condition (SC) and non-salinity condition (NSC) in Puccinellia distans exposed to foliar spraying of biostimulants. Different letters indicate significant differences according to LSD tests $(p<0.05)$.
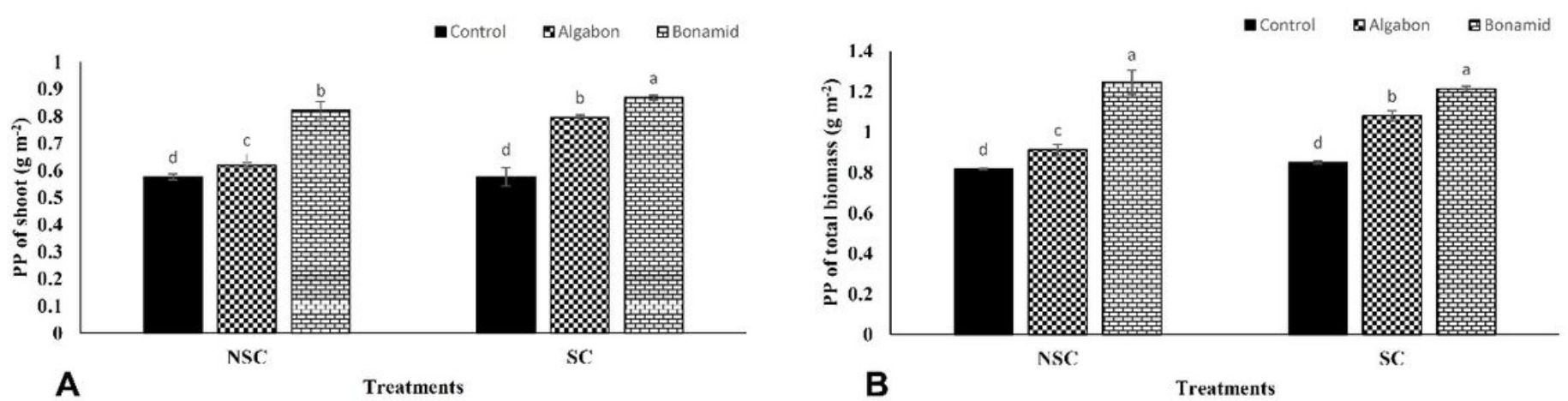

Figure 6

Phytoremediation potential of the shoots (A) and the total biomass (shoots+roots) (B) in salinity condition (SC) and nonsalinity condition (NSC) in Puccinellia distans exposed to foliar spraying of biostimulants. Different letters indicate significant differences according to LSD tests $(p<0.05)$. 

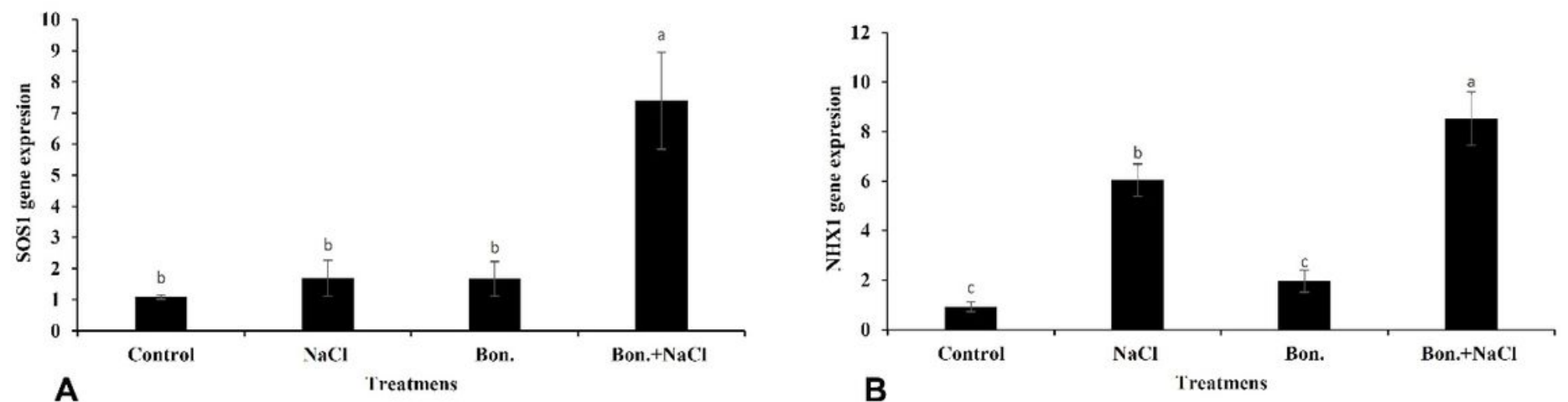

Figure 7

The expression induction of antiporter genes, SOS1 (A) and NHX1 in salinity condition (SC) and non-salinity condition (NSC) in Puccinellia distans exposed to foliar spraying of Bonamid. Different letters indicate significant differences according to LSD tests $(p<0.05)$. 